\title{
Family control and corporate cash holdings: Evidence from China
}

\author{
Qigui Liu, Tianpei Luo, Gary Gang Tian* \\ School of Accounting, Economics and Finance, University of Wollongong
}

\section{Abstract}

This study examines the effect of family control on the cash holding policy in China. We find that family firms with excess control rights tend to have high cash holdings that are tunneled rather than being invested or paid to shareholders. We further show that the incentive for controlling families to hold cash and for tunneling is exacerbated by the agency conflict between controlling and minority shareholders, i.e., it is weakened after the Chinese Nontradable share (NTS) reform and strengthened by the presence of multiple large shareholders who probably play no monitoring role in Chinese family firms. Furthermore, family firms’ incentive to hold cash for tunneling is influenced by the unique characteristics of Chinese firms in the following ways: the incentive is stronger when the family founder has one child and face family succession problem, and when the founder has political connections and directly involves in firm's management; while it is weakened by family founder's social interpersonal trust with other entrepreneurs through their membership of Chambers of Commerce. Overall, we argue that family firms in China tend to hold high levels of cash for tunneling, which harms firm value, while the severe controlling-minority shareholder agency conflicts and unique Chinese family characteristics only make this situation worse.

\section{Keywords: Cash holdings, family firms, Excess control rights, Family succession}

\footnotetext{
* Corresponding author. Tel: +612 4221 4301. Email address: gtian@uow.edu.au (Gary Tian). We appreciate the comments from the both the editor and the reviewers. We acknowledge the valuable suggestions and comments on this paper by Yasuhiro Arikawa, Jing Shi, Sinclair Davidson and other participants of the Asian Finance Association annual conference in Bali Indonesia, between June 24 and June 27, 2014 and the seminar organized by the School of Economics, Finance and Marketing, RMIT, Australia on June 30, 2014.
} 


\section{Introduction}

The record level of high cash holdings held by so many corporations worldwide has led to a fierce debate from both practice and research, regarding the motives for firms' holding so much cash. There are two classic explanations for corporate cash holding: operational considerations and the agency issue. The former argues that firms adjust their level of cash holdings according to the investment opportunities and financial constraints ${ }^{1}$, while the latter argues that the cash holding policy is mainly affected by agency conflicts between managers and shareholders, because managers have an incentive to hold more cash to pursue their private benefit ${ }^{2}$. However, little attention has been paid to the question of whether cash holding is affected by agency conflicts between controlling and minority shareholders, especially in family controlled firms (family firms thereafter) that are typically controlled by a few controlling families (La Porta et al., 1999; Claessens et al., 2002; and Faccio et al., 2010).

Family firms are a significant and common business feature around the world (Shleifer and Vishny, 1986; La Porta et al., 1999; Claessens et al., 2000; Faccio and Lang, 2002; Anderson and Reed, 2003; Villalonga and Amit, 2006; Bunkanwanicha et al., 2013), but whether family ownership, including founding-family ownership creates value to those firms is still a controversial issue. Anderson and Reeb (2003) and Villalonga and Amit (2006) find that founding family firms in the US perform better than non-family firms where ownership is widely dispersed. They argue that the founding family can reduce agency conflict between managers and shareholders, but recent studies have found that in emerging markets controlling families have strong incentive to pursue private benefit and expropriate minority

\footnotetext{
${ }^{1}$ See, for example, Duchin (2010); Denis and Sibikov (2010); Bates et al. (2009); Opler et al. (1999); and Kim et al. (1998); Almeida et al. (2013).

${ }^{2}$ See, for example, Gao et al. (2013); Harford et al. (2008); Dittmar and Smith (2007); Kalcheva and Lins (2007); Dittmar et al. (2003); and Harford (1999). The third motive for corporate cash holdings, which has recently become an important phenomenon in developed countries such as US, is present for multinational firms and is due to repatriation taxes (Sanchez and Yurdagul, 2013).
} 
shareholders and pursue activities that inevitably discredit the value of family firms (Cronqvist and Nilsson, 2003; La Porta et al., 1999; Claessens et al., 2002; and Faccio et al., 2010).

Previous studies have also confirmed that controlling shareholders with excess control rights tend to expropriate minority shareholders through higher levels of debt (Faccio et al., 2010), but there is still not enough evidence ${ }^{3}$ to prove whether a controlling family with excess control rights also retains high levels of cash to facilitate their expropriation given that cash and cash equivalent assets are easier to convert to private benefits at lower costs than other assets (Myers and Rajan, 1998). By investigating the effect of excess control on the corporate cash holding policy of Chinese family firms, this study aims to provide new explanations for the corporate cash holding policy of family firms in emerging markets. More specifically, this study aims to provide empirical evidence to answer the following questions: Do family firms hold more cash to tunnel? Does controlling families' incentive to hold cash for tunneling differ under different levels of the agency conflict between controlling and minority shareholders? How is the incentive for controlling families to hold cash and practice tunneling influenced by unique characteristics of Chinese family firms such as the Chinese one child policy and the associated family succession problem, family social networks and political connections, and family's direct involvement in management?

This study mainly focuses on family firms in the Chinese capital market but it also uses nonfamily firms as a control sample to reveal variations in the relationship between excess control rights and cash holdings in family and non-family firms. A potential endogeneity issue may arise from the fact that corporate cash holdings and other capital structure policies such as leverage, debt maturity, and dividend payouts are jointly determined (Al-Najjar,

\footnotetext{
${ }^{3}$ A recent study by Chen and Wang (2014) find that excess control rights are positively associated to the cash holdings of Taiwanese firms, but they do not reveal whether the relationship in family controlled firms exists or not, and they provide no further evidence about the relationship between excess control rights and tunneling.
} 
2013; Harford et al., 2014), so we use a three-stage least square (3SLS) simultaneous regression model to account for the endogeneity issue of cash holding. We also address the endogeneity issue by taking advantage of Chinese NTS reform as a natural experiment to see whether Chinese family firms adjust their cash holding policy when agency conflicts between controlling and minority shareholders were alleviated.

This study takes advantage of Chinese listed firms because of the unique features of Chinese family firms and the unique institutional settings in China. Family businesses are a significant and common business feature in the Chinese capital market. In the 2012 Forbes Chinese Family Business Report, family firms accounted for $49 \%$ of privately owned firms listed on the Chinese capital market, and unlike family firms in other countries, Chinese family firms are more liked to be expropriated by controlling families because the agency conflicts between controlling and minority shareholders are high due to the weak protection of minority shareholders. In reality the legal system in China is weak and it offers fewer options for minority shareholders to take private enforcement actions against block holder's misconduct, while public enforcement such as fines and prison terms for tunneling are hampered by the limited authority of security market regulators. All of this increases the risk of tunneling from controlling shareholders (Jiang et al., 2010), while the wide existence of excess control rights and the split share structure before the NTS reform only make the situation worse (Liu and Tian, 2012).

As Bennedsen et al. (2014) pointed out; family firms are an adaption to environmental opportunities and constraints, which makes it interesting to explore how the corporate cash holding policy of Chinese family firms are influenced by the following unique characteristics of Chinese family firms.

First, the Chinese government still intervenes into the operations of family firms even if they do not have ownership over them. This means the property rights of family founders have 
weak protection and founders of family firms face the very high risk of being taken over by large state controlled firms under the pressure of government intervention ${ }^{4}$. This may cause potential succession problems for family firms because most controlling families may be unwilling to pass the firms on to their descendants (instead family firms have a strong incentive to transfer their wealth to their descendants in western countries such as the US) and therefore intend to be actively involved in expropriation activities. Moreover, the family succession problem in Chinese family firms is also strengthened by the one child policy in China. Most Chinese family firms are run by the founders who are the first generation of these firms, but due to the one child policy, there is only one potential heir to most family firms. The potential succession problem arises from this unique policy (Bennedsen et al., 2014; Cao et al., 2014) because culturally, outsiders are usually not trusted in China, so having only one child significantly decreases the founder's expectations of having a young heir for succession (Cao et al., 2014). Thus most family businesses in China are likely to be sold because no direct family members would take care of the business after the first generation. Taken together, the potential family succession problem may have important impact on controlling shareholders' incentive to expropriate and corporate cash holding decisions of Chinese family firms.

Second, the US market is based on formal legal contracts whereas the Chinese business environment is mainly dominated by informal personal ties such as relationships and networks (so called 'Guanxi'). Under this institutional setting, it is very important for family founders to establish and maintain a good relationship with other entrepreneurs (social trust

\footnotetext{
${ }^{4}$ For example, RiZhao Steel Group CO, LTD, a privately owned steel company, was established by the founder, Du Shuanghua in 2003. The company was well managed and generated an annual profit of 6 billion Yuan (Equivalent to around US\$900 Million) in 2009. Mr Du was ranked as second in the Hurun Report of 2008, an annual ranking of China's wealthiest individuals. However, the government of Shandong Province announced that the company would be merged into the Shandong Steel Group, the state owned enterprise fully owned by the government of Shandong Province, because the provincial government wanted to streamline its steel sector in 2008. Although the founder did not want to lose the company, his company was finally acquired by its big state owned competitor due to the great pressure from the provincial government in 2009 (http://www.eeo.com.cn/ens/homepage/briefs/2010/11/05/184970.shtml).
} 
and connections), and with the government (political connections). Obviously then the personal characteristics of Chinese entrepreneurs may also influence corporate cash holdings of family firms given that they greatly influence the personal incentives of these entrepreneurs, who are usually controlling shareholders and founders of Chinese family firms.

Lastly, Chinese family firms are characterized by the deep involvement of family members in both management and the board of directors, which means they have enormous controlling power over the listed firms and there are fewer alternative views from other board directors; this often results in a poorer corporate governance mechanism. Therefore controlling families usually face less monitoring, and thus the risk of expropriation increases in family firms.

Our empirical results show that the excess control rights of controlling shareholders is positively associated with the corporate cash holdings of Chinese family firms. Furthermore, the large cash holdings in family firms with excess control rights are associated with more inter-corporate loans to controlling shareholders, more tunneling related party transactions (RPTs) and less capital expenses or distribution of dividends. This confirms our expropriation story that unlike other private firms, minority shareholders in family firms are more likely to be tunneled and the high level of cash holdings is a channel through which controlling shareholders tunnel resources from listed firms. Our empirical evidence further shows that the NTS reform which alleviated the agency problem between controlling and minority shareholders, effectively reduced the incentives of controlling families to hold cash for tunneling, while multiple large shareholders do not play a monitoring role in mitigating agency conflict between controlling and minority shareholders, they actually collude with the controlling shareholders.

By investigating how corporate cash holding and tunneling by controlling shareholders are influenced by the unique characteristics of Chinese family firms, we find that the incentive to 
hold cash for tunneling is exacerbated by the one child policy and associated succession problems, the family founder's political connections and direct involvement in management, but it is alleviated by family founders' interpersonal connections with other entrepreneurs who are also members of the Chinese Chamber of Commerce.

Finally, the evidence of robustness is provided to show that controlling shareholders are more likely to hold more cash for tunneling when firms have a sound financial condition even though they have no need to hold so much cash, and the marginal value of family firms with excess control rights that hold large amounts of cash is negative. Overall our additional findings all support our main argument that Chinese family firms tend to hold high levels of cash for tunneling, and it destroys firm value.

Our paper contributes to current literature in the following ways:

First of all, we contribute to literature on family firms; existing literature on family firms mainly focuses on the implications of family control on their value, and most studies use samples of US family firms (Bennedsen et al., 2014). But when listed firms in emerging markets such as China are used, where most family firms are run by the founders and the second type of agency issue dominates, our study reveals that family firms usually hold high levels of cash for tunneling, which harms firm value. Moreover, previous studies have documented the discounted value of family firms in some emerging markets, especially when the controlling families have excess control rights (Cronqvist and Nilsson, 2003; Amit et al., 2009), while our study confirms this discounted value in China.

More importantly, we find that the corporate cash holding policy and tunneling by controlling families are shaped by the unique characteristics of Chinese family firms, such as the potential family succession problems arising from the one child policy. Thus our study complements previous studies such as Bennedsen et al. (2007) and Cao et al. (2014) who 
both find that the family succession problem has a negative effect on firm performance. By providing empirical evidence that the cash holding policy of Chinese family firms is shaped by the unique characteristics of Chinese family firms, our study also supports the argument that family firms are an adaptation of environmental opportunities and constraints (Bennedsen et al., 2014; Jiang et al., 2014).

We also contribute to literature related to corporate cash holdings; previous studies mainly focus on the determinants of corporate cash holding policy, whereas we have extended the literature by investigating how corporate cash holdings differ in family and non-family firms and how cash holding policy is impacted by corporate ownership structure under the controlling-minority shareholders agency conflict framework. From this point of view we also contribute to literature on agency theory.

Finally, our findings have implications on our understanding of corporate cash holding policy in an emerging market. We document that firms' cash holding policy in an emerging market is mainly dominated by agency conflict between the controlling and minority shareholders, especially in family firms, although the incentive for controlling families to hold high levels of cash for tunneling is alleviated after the NTS reform due to the easing of agency conflicts between controlling and minority shareholders. However, having multiple large shareholders does not alleviate agency conflicts because they do not play an active monitory role in the tunneling behavior of controlling families like they do in developed markets (Maury and Pajuste, 2005; Bennedsen and Wolfenzon, 2000 and Bolton and Von Thadden, 1998).

The remainder of this paper is organized as follows: Section 2 develops our hypotheses. Section 3 describes our sample, data, variable measures, and chosen methodology. Section 4 presents the empirical results and interpretations, and section 5 summarizes and concludes the paper. 


\section{Hypothesis development}

\subsection{Excess control rights, corporate cash holding, and controlling shareholders' tunneling in family firms}

As discussed above, excess control rights in emerging markets usually destroy firm value because controlling shareholders tend to expropriate the interests of minority shareholders, especially in countries with poor shareholder protection system (Claessens et al., 2002; Lemmon and Lins, 2003; Faccio et al., 2010; Lin et al 2012; Liu and Tian, 2012). Thus we expect that controlling shareholders of firms with excess control rights are likely to hold more cash to pursue their private benefits because, in contrast to other assets, liquidity assets such as cash or cash equivalents can be more conveniently transformed into private benefits at lower costs (Myers and Rajan, 1998; Pinkowitz et al., 2006). Moreover, liquid assets are flexible and can be invested immediately into projects which benefit the controlling shareholders (Pinkowitz et al., 2006; Dittmar et al. 2003 and Kalcheva and Lin, 2007). When this is combined with the weak protection of minority shareholders in China, it is therefore reasonable to expect that controlling shareholders tend to hoard more cash to facilitate expropriation when they have excess control rights. Thus, we hypothesize that:

H1a: Excess control rights in family firms are positively associated to corporate cash holdings.

In addition, given that cash and cash equivalent assets can be turned into private benefits at lower costs than other assets, and it is also easier to make them disappear, liquidity assets such as cash and cash equivalents provide more tunneling opportunities for controlling shareholders. Cheung et al. (2006) show that most related party transactions and tunneling activities involve cash transfers, so we expect that the high cash holdings in family firms with excess control rights are also associated with more tunneling from controlling shareholders, 
especially in family firms. Using inter-corporate loans (Jiang et al. 2010) and tunneling RPTs (Cheung et al., 2006) as direct measures of controlling shareholders' tunneling, we hypothesize that:

H1b: Excess control rights are positively related to controlling shareholders' tunneling in family firms, especially in firms with high cash holding.

\subsection{Controlling-minority shareholder agency conflict, excess control rights and corporate cash holding/tunneling of controlling shareholders}

We argue that the incentive for Chinese family firms to hold cash is mainly driven by the tunneling of controlling shareholders that stems from severe agency conflicts between controlling and minority shareholders. Thus it is interesting to investigate whether the relationship between excess control rights and corporate cash holding/tunneling by controlling shareholders changes when the controlling-minority shareholder agency conflict is at a different level (before or after the NTS reform), or whether multiple large shareholders exist or not.

\subsubsection{The effect of the NTS reform on the relationship between excess control rights and corporate cash holding/tunneling of controlling shareholders}

Prior to the NTS reform, the unique Chinese split share structure caused severe agency conflicts between controlling and minority shareholders because the shares held by controlling shareholders were not tradable and therefore their wealth was not related to share price, so they were not concerned about being punished by the capital market. After the reform the incentive for controlling shareholders to expropriate decreased because the reform enabled controlling families to trade their shares, which significantly improved the alignment between controlling shareholders and minority shareholders (Firth et al., 2009; Beltratti et al., 
2011; Chen et al., 2012), and also reduced the incentive for controlling shareholders towards tunneling (Liu and Tian, 2012).

Since this reform affected all Chinese listed firms, it can be used as an endogenous shock to test whether cash holdings are used to tunneling by investigating the changes in firm's cash holdings when the controlling shareholders' incentives for tunneling were limited after the reform. We expect that if our argument is correct, we should see that the positive relationship between excess control rights and corporate cash holding/tunneling decreased after the NTS reform, so we hypothesize that:

H2a: The non-tradable share reform weakens the positive association between excess control rights and corporate cash holdings (controlling shareholders' tunneling) in family firms.

\subsubsection{The effect of multiple large shareholders on the relationship between excess control rights and corporate cash holding/tunneling of controlling shareholders}

The theoretical literature on the role played by multiple large shareholders (MLS) argues that they can either monitor the controlling shareholders (a monitoring incentive) or form controlling coalitions to share private benefits (a collusion incentive) (Maury and Pajuste, 2005; Bennedsen and Wolfenzon, 2000; Bolton and Von Thadden, 1998). Lehman and Weigand (2000) and Maury and Pajuste (2005) find that having strong second largest shareholders enhances profitability in European firms, while Faccio et al. (2001) find that MLS reduces expropriations in Europe and increases expropriations in Asia where the corporate governance and protection of investors are weak. Attig et al. (2008) further documents that the uneven distributed control rights reduces the monitoring efficiency from multiple block holders such that they could even form control coalitions and share private benefits through expropriations. 
Following previous studies, we expect that MLS in China is likely to collude with controlling shareholders due to the weak corporate governance and investor protection in China, especially in family firms because the control rights are highly concentrated in the hands of controlling families. Therefore, we develop the following hypothesis:

H2b: The interaction of excess control rights and block shareholder proxy is positively related to corporate cash holding (controlling shareholders' tunneling) in family firms.

\subsection{The effects of unique characteristics of Chinese family firms on the relationship between excess control rights and corporate cash holding/tunneling of controlling shareholders}

Previous literature has widely documented that the behavior of family firms are shaped by the culture, and psychological and social factors (Gomez-Mejia et al., 2011; Mehrotra et al., 2013; Gedajlovic et al., 2012; Bennedsen et al., 2014), so it is worthwhile investigating whether and how the unique characteristics of Chinese family firms influence our main argument that Chinese family firms with excess control rights tend to hold more cash for expropriation.

\subsubsection{The effect of one child policy and succession problem in Chinese family firms}

The first issue we are concerned with is the succession problem of Chinese family firms. As discussed in the sections above, compared to family firms in the US, the weak legal protection of property rights in China reduces the willingness of controlling families to pass the firms on to their descendants. This means that founding family firms in China are less likely to be concerned with their long term reputation, which increases their incentive to expropriation. Chinese family firms also differ with other family firms in Asia in other ways, such as the potential influence from the one-child policy on succession of family firms, even though this law was made for different purposes (Bennedsen et al., 2014). 
After the Chinese economic reform, the number of family firms increased significantly and many of the founders have now reached retirement age, but because of the one-child policy, they have fewer children than family firms in other Asian countries and therefore face serious human capital constraints for within-family succession (Bennedsen et al., 2014). Cao et al. (2014) find that the Chinese one-child policy has created a significant challenge for transferring family firms to the next generation, and having fewer children negatively affects family firms' reinvestment rates and reduces their research and development expenses. Since the one-child policy reduces the likelihood of founders transferring family firms to the next generation, we argue that this succession problem will increase the founders' incentives to expropriate because through expropriation they can retain their wealth within the family even though they will lose control after retirement. We therefore use whether the controlling family only has one family descendant as a proxy for potential succession problem to develop our hypothesis H3a as follows:

HЗa: The positive relationship between excess control rights and corporate cash holding (controlling shareholders' tunneling) is stronger in family firms whose founder only has one descendant.

To make our succession hypothesis complete, we also investigate whether family firms that have been passed on to their descendant (second generation), which means they do not have a succession problem, hold less cash and have less expropriation from the controlling family. Literature has documented the positive effect that second generation involvement has on firm performance in China (Xu et al., 2014). Our rationale is that if as expected the first generation founders in China tend to tunnel the interest of listed companies due to potential succession problems caused by the one-child policy, then family firms that have already been passed/are passing to second generations should alleviate tunneling incentives, which may result in 
having low levels of cash for tunneling in those firms. Thus we develop the following hypothesis to support our argument:

H3b: The positive relationship between excess control rights and corporate cash holding (controlling shareholders' tunneling) is weaker in family firms who have been passed/are passing to second generations.

\subsubsection{The effect of social trust and political connections in Chinese family firms}

Previous studies suggest that in emerging markets such as China, where the business environment is still dominated by informal constraints rather than formal institutions (Peng and Heath, 1996), social networks and other informal ties like Guanxi usually play an important role in corporate performance and decision making (Aguilera et al., 2008; Cao et al., 2014). One of the most important channels through which Chinese entrepreneurs establish social connections is the Chamber of Commerce, namely the All-China Federation of Industry \& Commerce (ACFIC), which is an informal club that brings entrepreneurs together based on trust and social connections. Luo (2003) and Li and Zhang (2007) argue that this informal relationship could be more trustworthy than formal legal contracts and also reduce information asymmetry between members. Family founders of the member firms of these Chambers usually have strong personal ties based on interpersonal trust (Stacchini and Degasperi, 2014) that can be very beneficial in the areas of trade credit and loan guarantees. We expect that the incentive for the founding families to expropriate may be reduced by this interpersonal trust because otherwise the family founder may sever their connections and lose the support of other members.

Therefore, we expect that the relationship between excess control and corporate cash holding is weaker in family firms controlled by a member of the executive committee of the Chambers of Commerce, and develop the following hypothesis: 
H3c: The positive relationship between excess control rights and corporate cash holding (controlling shareholders' tunneling) is weaker in family firms controlled by an executive member of Chambers of Commerce.

Political connections are widely documented to have an important impact on the financial policy of publicly listed firms, especially in emerging markets such as China with low quality government and large government intervention (Chen et al., 2011). Literature shows that Chinese family firms are discriminated against for accessing external financial resources (Cull and Xu, 2003; Firth et al., 2009; Li et al., 2009; Liu et al., 2013), so connected executives help to overcome this discrimination. However, literature mainly focuses on the political connections of executives (CEO or chairman) rather than the controlling shareholders. We expect that controlling families' political connections may facilitate their tunneling because they are less likely to face disciplinary constraints from regulators (Qian et al., 2011; Berkman et al., 2011) and are thus less likely to be disciplined by the capital market (Lemmon and Lins, 2003; Berkman et al., 2011). From this perspective we further hypothesize that the positive relationship between excess control rights and corporate cash holding is strengthened by controlling family's political connections and develop our last hypothesis as follows:

H3d: The positive relationship between excess control rights and corporate cash holding (controlling shareholders' tunneling) is stronger in family firms with political connections.

\subsubsection{The effect of family direct involvement in management of family firms}

The last characteristic of Chinese family firms is that controlling families are deeply involved in everyday management which causes more critical agency conflicts between controlling and minority shareholders and harms firm value (Cronqvist and Nilsson, 2003). Given that there are more severe agency problems in firms with direct family involvement, we develop 
our final hypothesis based on the controlling family's incentive to hold cash for expropriation is stronger in family firms with greater family involvement, that is:

H3e: The positive relationship between excess control rights and corporate cash holding (controlling shareholders' tunneling) is stronger in family firms with greater family involvement.

\section{Methodology and measurement of variables}

\subsection{Sample}

The sample used in this paper consists of all privately controlled firms (non-state owned firms, so called non-SOEs) listed on the Shanghai and Shenzhen stock exchanges from 2004 to 2011 , which is the largest sample we could obtain when we conduct our study ${ }^{5}$. However, we use the sample of observations from 2004 to three years after the year that the NTS reform was announced as being completed when we conduct our regressions on the effect of NTS reform on the relationship between excess control rights and corporate cash holding to keep the NTS reform as an exogenous stock because the NTS reform finished before the end of 2007 and thus firms' ownership structure is less likely to change until 2008 due to the post-reform lock up period for 1 to 3 years.

The data is collected from a series of datasets from the CSMAR database. It includes the Chinese listed firm annual report database from 2004 to 2011, the Chinese listed firm corporate governance database from 2004 to 2011, and the Chinese listed firm NTS reform database from 2005 to 2008. The listed state owned enterprises (SOEs) were excluded because the different objectives and principles and agency framework between SOEs and

\footnotetext{
${ }^{5}$ Our research period starts from 2004 because, from 2004, the China Securities Regulatory Commission (CSRC) required all Chinese listed firms to identify their ultimate owners and the controlling chains in their annual reports. The CSRC defines the ultimate owner of a publicly listed company as: the largest shareholder or the shareholder with more voting powers than the largest shareholder or the shareholder with shareholding or voting rights above $30 \%$ of the total shares or voting rights in the company or the shareholder who can determine over half of the board members.
} 
non-SOEs in China ${ }^{6}$. Moreover, Chinese family firms are all non-SOEs by definition, so they have a similar ownership structure and corporate governance characteristics to firms in other emerging markets. This is why most previous studies on corporate cash holdings focus on non-SOEs, and why we use the sample of non-SOEs to obtain comparable results with other studies (Faccio et al, 2010; Rousseau and Xiao, 2008). We also exclude all the firms from the financial industry because they have unique accounting standards and capital structures. To avoid having the new listings influence our results we also exclude firms who went public after 2004 because newly listed firms usually have extremely high levels of cash. We also excluded firms whose relevant data are missing and incomplete. To minimize the effect of outliers, we trimmed our sample at $1 \%$ on each variable in each tail. The final sample contains 2183 firm year observations (1201 family firms and 982 non-family firms) from year 2004 to 2011. All 12 non-financial industry dummies are included in our sample?

\subsection{Measurement of variables}

\subsubsection{Family firms}

Following Bunkanwanicha et al. (2013), we define a family firm where the founder and/or a member of their family by either blood or marriage own at least $20 \%$ of control rights directly and indirectly in a firm over the sample period. Direct ownership is held either by the founder and/or their family members, while indirect ownership is held by corporations which the family owned. We follow the approach introduced by La Port et al. (1999), Claessens et al. (2000) to trace the ultimate controlling shareholders in firms with pyramid ownership structure. According to our family firm definition, we divide our full sample of 2183 firm-

\footnotetext{
${ }^{6}$ SOEs in China have different objectives and principal-agent framework, compared to these non-SOEs, so the main agency issue in SOEs is the agency conflict between shareholders and managers rather than between controlling shareholders and minority shareholders (Rousseau and Xiao, 2008).

${ }^{7}$ According to the CSRC industry classification, the listed firms in Chinese capital market are classified into 12 industries. They are manufacturing, agriculture, mining hot water and electricity, construction, transportation, information technology, wholesale and retail, real estate, social service culture and broadcasting, and comprehensive.
} 
year observations into two subsamples that include 1201 family controlled observations and 982 non-family controlled observations.

\subsubsection{Other variables}

Following previous studies (Denis and Sibilkov, 2010; Ozkan and Ozkan, 2004), we measure corporate cash holdings as the ratio of cash and equivalent assets to total assets (CASHTA). We also introduce a dummy variable, HCASHM, to measure whether a firm's cash holding is higher or lower than the mean, which equals to 1 if their cash holding is above mean and 0 otherwise.

Controlling shareholders' tunneling is measured by the inter-corporate loan (Jiang et al., 2010) and RPTs that are more likely to be a tunneling activity (tunneling RPTs) (Cheung et al., 2006) in this study. Jiang et al. (2010) argue that inter-corporate loans are widely used by controlling shareholders to extract funds from listed firms. This form of tunneling is very severe when controlling shareholder's control rights are much larger than their cash flow rights. Although the CSRC has issued numbers of warnings and made its disclosure mandatory, weakly enforced regulations have meant that the practice has not abated (Liu and Tian, 2012). Following Jiang et al. (2010), this study uses ORECTA which is defined as other receivables scaled by total assets to measure inter-corporate loans to controlling shareholders. Cheung et al. (2006) classified firms RPTs into RPTs that are more likely to be related to tunneling and those that are related to propping. We follow their classification and created a dummy TUNNELING RPT which is a dummy variable that equals to 1 if the firm has RPT in a particular year and the RPT is related to tunneling and 0 if the firm has RPT but it is not related to tunneling. It is worth noting that our sample size is limited to firm-year observations that have RPTs only for regressions using TUNNELING RPT as the dependent variable. 
The key independent variable in this study is excess control rights (EXCESS), which is defined as the difference between the controlling shareholder's control rights and cash flow rights. Following previous research (Claessens et al., 2000; La Porta et al., 1999), cash flow rights are computed as the sum of the products of the percentage of ownership along the control chain where control rights are the minimum percentage of ownership along the control chains. We also include CASHFLOW in our regression to control the ultimate owner's incentive not to tunnel which is the total cash flow rights of the controlling shareholder.

We define the post-reform period as three years after the year that the reform was announced as being completed, for instance, if a firm was to be reformed in June 2006, the post-reform period is the firm year observation from 2006 to 2008. Since there is normally a three year lock up period after the reform, a firm's ownership structure could not change very much during the three year period afterwards, which makes the reform an exogenous shock (Liu and Tian, 2012). Therefore REFORM is a dummy variable which equals to 1 for firm year observations in the post NTS reform period and equals to 0 for firm year observations before the NTS reform period ${ }^{8}$. A multiple large shareholder structure in is measured in this paper by the following two proxies, following previous studies by Attig et al. (2008): SECONDLARGE, which is a dummy variable that takes the value of 1 if the firm has a second largest shareholder with no affiliation to the ultimate owner, but with more than $5 \%$ control rights, and zero otherwise; SUM2_10 is the number of shareholders who hold more than $5 \%$ control rights from the second to tenth largest shareholders but without any affiliation with the ultimate owners.

A series of dummy variables are defined to proxy the unique characteristics of Chinese family firms. ONECHILD is a dummy that equals to 1 if the ultimate controlling shareholder

\footnotetext{
${ }^{8}$ Please note this will make our sample size smaller for regressions on the effect of the NTS reform and excess control rights on corporate cash holding in Tables 6 and 7.
} 
of the family firm only has one child and 0 otherwise. DESCENDENT is a dummy that equals to 1 if the firm has been passed or is passing to the second generation and 0 otherwise, and it is a measure of whether the firm has a succession problem or not. SOCIALTRUST is a dummy that equals to 1 if the firm's ultimate controlling shareholder is an executive member of the ACFIC that is recognized as the most important non-governmental chamber in China and 0 otherwise ${ }^{9}$. POLITICAL is a dummy that equals to 1 if the firm's ultimate controlling shareholder is politically connected ${ }^{10}$ and 0 otherwise. And finally, FAMILYCEO is defined as a dummy that equals to 1 if members of the controlling family are involved in firm management and business operations as the CEO or chairman.

Following previous literature on corporate cash holdings, this study also includes several other firm specific control variables; detailed definitions of all the variables are listed in Appendix A.

\subsection{Methodology and regression models ${ }^{11}$}

It has been well documented that corporate cash holding is not exogenous, i.e., it is most likely jointly determined with other corporate policies such as leverage, debt maturity, and dividend payouts (Harford et al., 2014; Al-Najjar, 2013). Consequently this study follows the methodological approach taken by Harford et al. (2014) and uses a simultaneous equations framework where cash holdings and other corporate policies such as leverage, debt maturity, and dividend payouts are treated as endogenous ${ }^{12}$. Particularly, we estimate a three-stage

\footnotetext{
${ }^{9}$ It is likely that the entrepreneurs of Chinese family firms are both an executive member of ACFIC and have political connections. In order to avoid the influence from political connections, our definition of SOCIALTRUST only include firms whose ultimate controlling shareholders are member of ACFIC but without political connections.

${ }^{10}$ Following previous studies such as Fan et al. (2007) and Liu et al. (2013), a person is defined as politically connected, if he/she is currently working or was formerly an officer of the government or military or a deputy of the People's Congress or People's Political Consultative Conference.

${ }^{11}$ We appreciate the reviewer's comment for this addition.

${ }^{12}$ Harford et al. (2014) use a 2SLS system of equations to address the endogeneity issue of cash holding. As discussed by Zellner and Theil (1962), Cornwell et al. (1992) and Larcker and Rusticus (2010), 3SLS goes one step further compared to 2SLS, so it is better at dealing with the endogenous issue. However, to ensure that our
} 
least-squares (3SLS) system of equations to address the endogeneity issue by establishing four separate OLS regressions for cash holdings, maturity of debt, capital structure and dividend policy in order to develop the instrumented values for each endogenous variable. These instrumented values are recognized as the predicted values resulting from a regression of each endogenous variable on all exogenous variables in the system. We then obtain a consistent estimate for the covariance matrix of the equation disturbances that are based on the residuals from a two-stage least squares estimation of each structural equation. Finally, we simultaneously estimate four equations by including the covariance matrix estimated from the second stage and instrumented values from the first stage as independent variables. Thus the four baseline regression models are estimated simultaneously.

Although we establish four separate regression models to be estimated simultaneously, we only report the one where corporate cash holding (or controlling shareholder's tunneling ${ }^{13}$ ) is used as the dependent variable (Model 1), which is our main focus; the other regression models are not reported to save space ${ }^{14}$. Please note that model 1 is only a baseline regression model, new variables may be added to the model later to interact with our main independent variable: excess control rights (EXCESS).

Cash or Tunneling $=\alpha_{0}+\beta_{1} \times$ EXCESS $_{i, t}+\beta_{2} \times$ Control variables $_{i, t}+\beta_{3} \times$ Year and Industry Dummy $+\varepsilon$

For our Model 1, the dependent variable is the ratio of cash and cash equivalent assets to total assets. In addition to the key independent variable EXCESS, we also include the following control variables when the corporate cash holding is a dependent variable: CASHFLOW,

results are robust, we also redo all our tests using 2SLS approach, and the results are very similar to our results from 3SLS. The 2SLS regression results are not reported to save space.

${ }^{13}$ We use inter-corporate loan as developed by Jiang et al. (2010) as our main measure of tunnelling, as this variable is also related to the corporate policy. We also treat it as an endogeneity variable, and 3SLS simultaneous system regression models are applied to all regressions with inter-corporate loan as dependent variables. In addition, we also use RPT as an alternative measure of tunnelling in separate regressions as robustness tests.

${ }^{14}$ We can provide the regression results for other simultaneous equations if requested. 
BOARDIND, DUALITY, SECONDLARGE, LEVERAGE, DIVTE, OPCF-SD, SIZE, OPCFTA, M2B, SEO and DEBT MATURITY. When an inter-corporate loan is a dependent variable the control variables include: CASHFLOW, BOARDIND, DUALITY, SECONDLARGE, LEVERAGE, SIZE, OPCFTA, and ROA ${ }^{15}$. Year and industry fixed effects were controlled for in all of the above four models.

\section{Empirical results}

\subsection{Sample description and univariate tests}

Table 1 presents the descriptive statistics and univariate test of our sample. Panel A of table 1 presents the descriptive statistics for our whole sample, and panels B and C report the univariate tests of our main dependent variables based on different subsamples. The difference-in-difference method is used to test the changes in corporate cash holding policy and controlling shareholders' tunneling incentive before and after the NTS reform. The results in panel A show that the average cash to total assets of family firms is $17 \%$. Regardless of the differences in the institutional environments of China and United States, the average corporate cash holdings are similar to U.S. firms, as was documented by Opler et al. (1999). However, for those firms with high cash holdings, Chinese family firms hold much more cash than the US firms. The 75th percentile of cash to total assets in China is $22 \%$, but this ratio is only $17 \%$ in the US. Panel A also shows that the ratio of other receivables to total assets is on average 3\%. Although Jiang et al. (2010) report that from 1996 to 2004 the

\footnotetext{
${ }^{15}$ Other three models are: For Model 2, the dependent variable is maturity of debt as measured as the maturity of debt as the ratio of short term debt to the total long term debt. The independent variables in this regression include the ratio of cash and cash equivalent assets to total assets, market to book ratio, the natural logarithm of book value of total assets, cash flow risk which is measured by the standard deviation if operation cash flow to total assets, and term structure which is the difference between the yield on one year government bond and that on ten years government bond. For Model 3, the dependent variable is the leverage ratio. The independent variables include the ratio of cash and cash equivalent assets to total assets, the ratio of fixed asset to total assets, natural logarithm of book value of total assets, sales growth, the effective tax rate which is measured by the ratio of total tax payment to total assets and the ratio of pre-tax profit to total assets. For Model 4, the dependent variable is the ratio of dividend payment to earnings. The independent variables include following variables: the ratio of cash and cash equivalent assets to total assets, market to book ratio, natural logarithm of total book value of assets, leverage ratio, sales growth rate and management ownership.
} 
average ratio of other receivable to total assets was $8.1 \%$, our results show that this ratio decreased significantly in our sample period from 2004 to 2011. This indicates that tunneling activities as measured by inter-corporate loans, has decreased markedly in recent years. Of the 757 firm-year observations that have RPTs, 68\% are related to tunneling, and our results show that the average capital expenditure was $5 \%$ to total assets and the average payout ratio was $32 \%$.

Panel B of Table 1 reports the univariate test of our main dependent variables for firms with high and low excess control rights in family firms. The results indicate that family firms with more excess control rights hoard much more cash and cash equivalent assets and they also have significantly more inter-corporate loans (tunneling RPTs) than firms with low excess control rights; this is consistent with our hypotheses H1a and H1b.

In panel $\mathrm{C}$ we present the difference-in-difference tests of cash holdings for family firms with high or low levels of excess control rights, before and after NTS reform, and with and without different family characteristics. As expected, the corporate cash holdings decreased significantly after the NTS reform, especially for that group of firms with high levels of excess control rights. Moreover, our findings suggest that in the group of firms with high levels of excess control rights, family firms with multiple large shareholders, firms whose controlling shareholder has one child, firms whose controlling shareholder has political connections, and firms whose controlling family is involved in management have significantly higher cash holdings than firms without such characteristics. In the meantime, family firms run by family descendants and whose controlling shareholders have personal social connections, have significantly lower levels of cash holdings than firms without such characteristics in that group of firms with high levels of excess control rights. The differencein-difference tests are all statistically significant. Similar results are found from the univariate 
test of inter-corporate loans in panel D. Overall, our difference-in-difference tests in panels C and D support our hypotheses H2a, H2b, H3a, H3b, H3c, H3d and H3e.

$<$ Table $1>$

\subsection{Do family firms with excess control rights hold more cash?}

We begin our empirical examination from the 3SLS simultaneous estimation of the effect of excess control rights on cash holdings in both family and non-family firms, and where endogenous variables are corporate cash holdings, debt maturity, leverage ratio and dividend payout ratio. The results are reported in Table 2. Column 1 of Table 2 reports the regression results for our regression model 1 for a pooled sample that includes family and non-family firms, while columns 2 and 3 reports our regression results of family and non-family firms separately.

We find from column 1 that excess control rights are positively related to corporate cash holdings in the whole sample, but the coefficient is insignificant. The probable reason may be that excess control rights have a different impact on the cash holdings of family and nonfamily firms.

We further find that the coefficient of EXCESS is positive and is statistically significant at $1 \%$ level of significance in family firms, as reported in column 2 . This result indicates that controlling families tend to hold more cash, which is consistent with our hypothesis H1a. In the meantime, in the non-family controlled subsample (column 3), EXCESS is negative related to corporate cash holdings and is statistically insignificant, indicating that non-family firms with more excess control rights do not have higher cash levels, which is just as we expected.

Table 2 also provides information about the operational determinants of corporate cash holdings through the coefficients of other independent variables. Most of these independent 
variables are statistically significant and consistent with previous findings in Chinese capital market from Chen et al. (2012) and those findings that used the U.S. data (Opler et al., 1999). For instance, the positive relationship between operational cash flow (OPCFTA) and corporate cash holding supports the financial hierarchy theory (Opler et al., 1999). Leverage is negatively and statistically significantly related to cash holdings, which is consistent with Ozkan and Ozkan (2004), Al-Najjar (2013), and Harford et al. (2014) who argue that debt is a substitute for holding high levels of cash, and that higher leverage increases the interest payment, and therefore reduces the ability of firms to hoard cash. We also find that firms that pay dividends hold significantly less cash than firms that do not pay dividends, which is consistent with Opler et al. (1999) and Harford et al. (2014) who find the same results from firms listed in the US market. Seasonal equity offering (SEO) is found to be statistically positively associated to corporate cash holding, this is a reasonable result given that firms usually have high levels of cash following the SEO. Finally, board independence is positively but statistically insignificantly related to the corporate cash holdings of family firms, indicating that independent directors do not play an active monitoring role in family firms.

Overall, the results from table 2 confirm our H1a and indicate that the excess control rights of controlling shareholders are associated with higher cash holdings in family firms in China. In the following sections we will provide further evidence to our argument that the high cash holdings in family firms with excess control rights is tunneled by controlling shareholders, and this is driven by the agency conflict between controlling family and minority shareholders.

$<$ Table 2>

\subsection{Why do family firms with excess control rights hold more cash?}


In the previous section, our study confirms the positive relationship that exists between excess control rights and corporate cash holdings in family firms, but it is still not clear why they hold such high levels of cash. Generally speaking, firms may use their cash to tunnel, to invest, or distribute to shareholders. In this section, we attempt to answer this question by investigating how the high level of cash holding in family firms with excess control rights influence controlling shareholder's tunneling, capital expenditure, and dividend payout ratio. Again, corporate policy variables such as corporate cash holdings, inter-corporate loans, capital expenditure, and payout ratios are all endogenous choices made by the firm, so we further estimate a simultaneous 3SLS simultaneous estimation where the HCASHM dummy, inter-corporate loans, capital expenditure, and the dividend payout ratio are treated as endogenous variables. Our main argument will be supported if we find that firms with excess control rights and high cash holdings have more tunneling rather than more capital expenditure or dividend payout ratios.

\subsubsection{The effect of excess control rights and cash holding on tunneling: intercorporate loans as proxy of tunneling}

Table 3 presents the results of the effect of excess control rights and high corporate cash holding dummy on controlling shareholders' tunneling of family firms (columns 1-2) and other privately controlled firms (columns 3-4). The results first show that excess control rights are positively and statistically significantly related to inter-corporate loans (ORECTA) in our regressions. This result is consistent with the view that tunneling through intercorporate loans is worse when controlling shareholders have excess control rights (Jiang et al., 2010). More importantly, the results in column 2 show that the coefficient of the interaction term (HCASHM*EXCESS) is 0.45 and statistically significant at the $1 \%$ level of significance in family firms, while the results of the sum test show that the sum of EXCESS and HCASHM*EXCESS are also statistically significantly positive. These results confirm 
that the high cash holdings in family firms with more excess control rights are associated to more tunneling, which is consistent to H1b. However, this result is not found in non-family firms, as reported in column 4.

$<$ Table 3>

Overall, our findings in Table 3 support our expectation that the high cash holding in family firms are tunneled by controlling shareholders.

\subsubsection{Alternative explanations: Tunneling versus investment/dividend}

From previous section we find that the interaction between excess control rights and high cash holdings increases the tunneling from controlling shareholders in family firms. However, there are alternative explanations because those high cash holdings could also lead to more investment in positive net present value projects and high dividend payouts, so we investigated whether the high cash holding in family firms with excess control rights would also lead to higher capital expenditure and payouts. If, as we expected, high cash holdings in family firms are mainly used to facilitate controlling shareholders expropriations, we should not see a statistically significantly higher capital expenditure and payout in family firms with more excess control rights than those with less excess control rights. Our empirical tests results are reported in panels $\mathrm{A}$ and $\mathrm{B}$ of Table 4.

From column 4 of panel A, we find that the coefficient of HCASHM*EXCESS is negative and statistically significant at the $1 \%$ significance level in family firms, and significantly positive in other private firms. This indicates that the high cash holdings in family firms with excess control rights is not used to invest in positive net present value projects.

Similarly, we find from panel B that a family firm with excess control rights pay far less dividends when they hold higher levels of cash (the interaction term is negatively and 
significantly correlated with the dividend payout ratio), but no significant relationship is observed in non-family firms.

$<$ Table 4>

The overall results from Tables 3 and 4 suggest that family firms with more excess control rights hold high cash holdings for tunneling rather than for investing or paying dividends, which strongly supports our hypothesis H1b.

\subsubsection{The effect of excess control rights on tunneling/investment/dividend in subsample of family firms with high or low cash holding}

To ensure that our results are robust, we carried out further regressions to see whether the effect that excess control rights has on tunneling, investment, and dividends differs between firms with high and low levels of cash holdings. To do this, we divided our family firms into subsamples: firms with high level of cash holding vs. firms with low level of cash holding, based on whether the firms' cash holding is above or below the median. We then examine whether excess control rights have a different effect on tunneling, investments, and dividends in family firms for the two subsamples using the 3SLS simultaneous regression model. The results are reported below in Table 5 .

Consistent with our results in Tables 3 and 4, the results in Table 5 show that firms with excess control rights experience significantly much more tunneling, and significantly less investment when their level of cash holdings is high, even though the difference in dividends was insignificant. This suggested that the high corporate cash holdings in firms with excess control rights are tunneled rather than invested, which provides additional evidence to our hypothesis H1b.

$<$ Table 5> 


\subsubsection{The effect of excess control rights and cash holding on tunneling: tunneling related party transactions (Tunneling RPTs) as proxy of tunneling}

Related party transactions (RPTs) have been identified as important channels through which controlling shareholders tunnel or prop the listed companies (Cheung et al., 2006; Peng et al., 2011). If controlling shareholders with more excess control rights hold more cash for tunneling, we should expect that they are more likely to have RPTs, especially RPTs that would result in expropriation of minority shareholders ${ }^{16}$ (Cheung et al., 2006). In order to provide additional evidence to our argument, we further examine the effect that excess control rights would have on the likelihood of firms to have tunneling RPTs, using the dummy TUNNELING RPT as dependent variables.

As with our results in Table 3, the results in the first two columns of Table 6 show that family firms with more excess control rights are associated with a much higher probability of tunneling RPTs, especially those firms with high cash holdings. Similarly, Columns 5-6 also confirm the significantly positive relationship between excess control rights and the probability of having tunneling RPTs, which is consistent with our results in Table 5 where we use inter-corporate loans as a proxy for controlling shareholders' tunneling. But such a relationship is not found in non-family controlled firms. Our results in Table 6 further support our hypothesis H1b.

$<$ Table 6>

\subsection{How is the relationship between excess control rights and corporate cash holding/controlling shareholders' tunneling influenced by the agency conflicts between controlling and minority shareholders?}

\footnotetext{
${ }^{16}$ Cheung et al. (2006) classify RPTs into the following types: RPTs that are a priori likely to result in expropriation of the listed firm's minority shareholders; RPTs that are likely to benefit the listed firm's minority shareholders; and RPTs that may have strategic rationales and may not be expropriation.
} 


\subsubsection{Do family firms with excess control rights reduce cash holding/controlling shareholders' tunneling after the NTS reform?}

As discussed earlier, this study uses the NTS reform as an endogenous shock to test whether cash holdings are used for tunneling by investigating the changes of firm's cash holdings when the interests of the controlling and minority shareholders are aligned, which means that the incentive for controlling shareholders towards tunneling is reduced after the reforms. To do this, we further examine whether and how the interaction of excess control rights and the NTS reform dummy influence the corporate cash holding and tunneling of controlling shareholders. Table 7 tabulates the results and panel A and B report the results using corporate cash holdings and inter-corporate loans as dependent variables respectively.

As expected, the estimated coefficient of interaction between the reform dummy and excess control rights (REFORM*EXCESS) is negative and statistically significant in family firms (reported in column 2 of panel A). This result suggests that 1\% increases of excess control rights in family firms results in a $0.24 \%$ point increases in cash holdings before the NTS reform, but it only causes $0.06 \%(0.24 \%-0.18 \%)$ point increases in cash holdings of family firms after the NTS reform. These results indicate that corporate cash holdings decrease significantly after the NTS reform, which aligns the interests of controlling and minority shareholders, and thus reduces the controlling family's incentive to expropriate.

Similar results are shown in columns 1 and 2 of panel B where inter-corporate loans by controlling families in firms with excess control rights also decrease significantly after the NTS reform, whereas the results from columns 3 and 4 of both panels indicate that NTS reform does not have a significant influence on the relationship between excess control rights and cash holding/tunneling by non-family firms. 
Overall, the results in Table 7 confirm that corporate cash holdings and tunneling in family firms both decrease significantly after the NTS reform. Overall, the results in Table 7 support hypothesis H2a.

$<$ Table 7>

\subsubsection{Does the presence of multiple large shareholders reduce controlling shareholders' incentive to hold cash and tunneling?}

In order to address the issue of whether the presence of multiple large shareholders plays a monitoring or colluding role in family firms, we further examine the effect of excess control rights and proxies of multiple large shareholders on corporate cash holding/controlling shareholders tunneling. The results are reported in panels A and B of Table 8.

As expected, the results in panel A show that both proxies for multiple large shareholders (SUM2_10 and SECONDLARGE) have a significantly positive impact on the relationship between excess control rights and corporate cash holding of family firms (columns 1-2), but there were no significant results in other non-family firms (columns 3-4). These results suggest that the presence of multiple large shareholders plays a collusive role in family firms, while multiple large shareholders do not collude with the controlling shareholders of other privately controlled firms. Similar results are observed in panel B which shows that family firms with excess control rights tend to have more tunneling from controlling shareholders when multiple block holders are present.

<Table 8>

\subsection{Is the relationship between excess control rights and corporate cash holding influenced by unique characteristics of Chinese family firms? ${ }^{17}$}

\footnotetext{
${ }^{17}$ We appreciate the reviewer's comment for this addition.
} 
In this subsection we investigate how the relationship between excess control rights and corporate cash holdings is influenced by the unique characteristics of Chinese family firms. As discussed previously, Chinese family firms have some unique characteristics that differ from those in other markets, and these characteristics are expected to have an important influence on the controlling family's incentive to expropriate, and the related policy of cash holdings. In this subsection we aim to provide empirical evidence to the question about how the relationship between excess control rights and corporate cash holdings in family firms are influenced by those unique characteristics. Since we focus on the unique characteristics of Chinese family firms, the results for non-family firms are no longer reported.

\subsubsection{One child policy, family succession and the relationship between excess control rights and corporate cash holding/tunneling}

In order to provide empirical evidence for our hypotheses $\mathrm{H} 3 \mathrm{a}$ and $\mathrm{H} 3 \mathrm{~b}$, we examine the effect that ONECHILD and DESCENDANT, as defined in section 3.2.2, has on the relationship between excess control rights and corporate cash holding/inter-corporate loans. The results are reported in Tables 9.

As expected, our results show that family firms tend to hold more cash when the founder has one child, which means the founder is more likely to face succession problems and this effect is strengthened by their excess control rights. We further provide direct evidence that controlling families tend to expropriate more when they have excess control rights and face succession problem (have one child).

Although most Chinese family firms are still run by their founders, we still collect a sample of 39 firms (222 firm year observations) that have passed or are being passed to their descendants. Interestingly, a lower level of corporate cash holdings and an alleviated tunneling problem are found in family firms with no succession problems, based on the fact 
that the interaction term EXCESS*DESCENDANT is statistically significantly and negatively correlated to the corporate cash holding/inter-corporate loans to controlling families (see the results in columns 5-8 of Table 9).

Overall, our hypotheses HЗa and H3b are both supported here which suggests that expropriation by the controlling family is strengthened by potential family succession problems and alleviated when the succession problem is solved. These findings are consistent with $\mathrm{Xu}$ et al. (2014) who find that Chinese family firms who do not have succession problems performed better.

$<$ Table 9>

\subsubsection{Social trust, political connections and the relationship between excess control rights and corporate cash holding/tunneling}

In this subsection, we investigate whether and how the personal characteristics of controlling shareholders: social and political connections (SOCIALTRUST and POLITICAL), influence controlling shareholders' tunneling (inter-corporate loans) and the associated corporate cash holding policy. The results are reported below in Table 10.

As expected, the results in Table 10 suggest that the ultimate controlling shareholders' personal social connections (inter-personal trust) help to reduce expropriation by the controlling shareholder and the related high levels of corporate cash holding, whereas their expropriation and incentive to hold cash are aggravated by their personal political connections. Therefore, our hypotheses H3c and H3d are supported, which suggests that the incentive for controlling families to hold cash and expropriate are influenced by their personal connections such that social connections mitigate the incentive while political connections compound the problem. This supports previous literature such as Cao et al. (2014) and Qian et al. (2011). 
$<$ Table 10>

\subsubsection{Family direct involvement, excess control rights and cash holdings/tunneling}

Our regression results on how corporate cash holding and expropriation by the controlling shareholder are influenced by the involvement of family in management are reported in Table 11.

In column 1, our results show that excess control rights and family management involvement are both positively related to corporate cash holdings. More importantly, the estimated coefficient of the interaction term (EXCESS*FAMILYCEO) is also statistically significantly positive whether we use corporate cash holdings or inter-corporate loans as the dependent variables; this suggests that family firms tend to hold more cash for tunneling when they have excess control rights and direct family involvement.

Overall, our results in Table 11 suggest that the relationship between excess control rights and corporate cash holding/inter-corporate loans is strengthened in family firms if the founder is directly involved in firm management and business operations. These results support hypothesis НЗe where family management involvement is the main channel through which the controlling family tunnels the interest of minority shareholders, and it is consistent with previous studies by Cronqvist and Nilsson (2003) who find that family involvement causes more serious agency conflicts between controlling and minority shareholders.

$<$ Table 11>

\subsection{Dynamic relationship between controlling shareholders' tunneling and corporate cash holding $^{18}$}

In the sections above we provided substantial evidence to support our main argument based on a 3SLS simultaneous structural model that accounts for the endogeneity of corporate cash

\footnotetext{
${ }^{18}$ We appreciate the reviewer's comment for this addition.
} 
holdings and other corporate policy variables. In this subsection, we aim to develop some new regression models to examine the dynamic relationship between tunneling and corporate cash holdings. The rationale is: if a firm tends to use cash for tunneling then the level of cash holdings should drop subsequently following the tunneling by the controlling shareholders.

\subsubsection{Controlling shareholders' tunneling and corporate cash holding: GMM dynamic estimation}

Following Ozkan and Ozkan (2004), this study uses the Generalized Method of Moments (GMM) estimation for dynamic panel data to address the endogeneity issue using lagged values of variables and disturbances.

Table 12 presents the GMM dynamic estimation results where corporate cash holding is a dependent variable, independent variables are treated as endogenous variables, and lagged values are also included as instruments. We conduct separate regressions on different subsamples of firms with high and low levels of excess control rights to highlight the different dynamic relationships between tunneling and cash holding in firms with different level of excess control rights. The coefficient of the lagged value of inter-corporate loans is statistically significantly negatively related to corporate cash holding only in the subsample of family firms with high levels of excess control rights, which suggests that when the controlling family tunneled more from family firms in the previous year, the level of corporate cash holdings dropped subsequently, and which is consistent with our expectations.

$<$ Table 12>

\subsubsection{The effect of change of controlling shareholders' tunneling on change of corporate cash holding}

We have revealed the dynamic relationship between the level of corporate cash holdings and controlling shareholders' tunneling, where the level of cash holdings dropped significantly 
after a high level of tunneling in the previous year. In this subsection, we examine how the change of tunneling in the previous year influences the change in cash holding of family firms in order to expound the dynamic inference between tunneling and corporate cash holding. Table 13 reports the results. It is clear that the change of tunneling in previous year $\left(\triangle\right.$ ORECTA $\left._{\mathrm{t}-1}\right)$ is statistically negatively associated to the change of corporate cash holding ( $\triangle$ CASHTA) in family firms with more excess control rights. Our results are consistent with the results in Table 12.

$<$ Table 13>

\subsection{Additional tests}

To provide further supporting evidence for our results, we conduct a series of new regressions to investigate whether the incentive of controlling shareholders to hold cash for tunneling differs between financially distressed and non-financially distressed firms, as well as firms with a different need to hold cash. We also examine whether the cash holdings in family firms with excess control rights creates or destroys value. And finally, we match family firms with non-family firms using the propensity score matching method with the aim of ruling out other alternative explanations from our results.

\subsubsection{Financial distressed vs non-financial distressed firms}

Friedman et al. (2003) documents that controlling shareholders may choose either tunneling or propping depending on their cost and benefit. Further studies by Peng et al. (2011) find that controlling shareholders in China are more likely to have tunneling (propping) when the firm is in a sound financial condition (financially distressed). We therefore examine whether cash holding and tunneling differs between financially distressed and non-financially distressed firms by dividing our family sample into two subsamples: financially distressed 
and non-family distressed firms depending on whether the operation income/interest payment was below or above 1 .

Table 14 presents the results of the structural regression on the effect of excess control on corporate cash holding and inter-corporate loans in financially distressed and non-financially distressed firms. Table 14 indicates that statistically significantly positive relationship between excess control rights and corporate cash holding (inter-corporate loans) exists in the subsample of non-distressed firms, which is consistent with Peng et al. (2011).

$<$ Table 14>

\subsubsection{The effect of excess control rights on corporate cash holding in firms with different need to hold cash}

Our results in above sections provide evidence for our main hypothesis that family firms in China hold more cash for tunneling. We do not consider whether firms' incentive to hold cash may also be influenced by their need for cash. For instance, firms' high cash holdings can also be explained by the need to finance profitable growth opportunities, by hedging needs or cash flow uncertainty (Myers and Majluf, 1984; Acharya et al., 2007; Riddick and Whited; 2009). In order to rule out those alternative assumptions, we test the effect of excess control rights on corporate cash holding in family firms with high and low levels of the need for cash. The results are reported in Table 15.

Table 15 indicates that family firms with more excess control rights hold significantly more cash when their growth opportunity (cash flow uncertainty) is low; this means that family firms with excess control rights tend to hold more cash even when they do not need high levels of cash. Overall, our findings suggest that the high levels of cash in family firms is mainly driven by the agency conflict between controlling and minority shareholders rather than their need for cash, which supports our main story. 
$<$ Table 15>

\subsubsection{The effect of corporate cash holding on firm value}

Since controlling shareholders in family firms with excess control rights use additional cash to tunneling, the value of cash in these firms should be discounted. We thus expect that high cash holdings in family firms should not have a positive effect on firm value, so we examine the marginal value of cash holding (CASHTA) and excess cash holding (EXCASHTA) in family firms. Table 16 presents the results.

As expected, in columns 1 and 2, the interaction term of cash and high excess control rights dummy (CASHTA*HIGHEXCESS) has a negative impact on firm value in family firms, which indicates that holding cash does not add value to family firms with high excess control rights. In columns 3 and 4, we report the results using EXCASHTA, which is defined as the differences between actual cash holdings and predicted cash holdings, as a measure of excess cash holdings. The predicted cash holdings are calculated from equation 1 , and indicate that the marginal value of excess cash holding is also negative for family firms with high excess control rights. Overall, our results in Table 16 support our main argument that high cash holdings in family firms are used for tunneling and it decreases firm value.

$<$ Table 16>

\subsubsection{Family firms versus non-family firms: matching sample results}

We have documented that the positive relationship between excess control rights and corporate cash holding only exists in family firms. However, one potential question is that the ownership structure may be different in the two subsamples, that is to say, the difference in the relationship between excess control rights and corporate cash holding in family and nonfamily firms may be caused by the difference in ownership structure rather than family 
control. Thus in this section, we attempt to address this issue by conducting the following tests.

We first compare the ownership structure between family and non-family firms and report the results in Panel A of Table 17. There was no significant difference in terms of the percentage of firms with excess control rights and the level of excess control rights ${ }^{19}$, which suggests that the ownership structure does not vary much between family and non-family firms. Second, following Amit et al. (2009), we divide non-family firms into three types: firms controlled by collective organizations, firms controlled by foreign investors, and firms controlled by other types of investors. The distribution of those different types of firms is reported in panel $\mathrm{B}$, which shows that most non-family controlled firms are controlled by collective organizations. We then examine the effect of excess control rights on the corporate cash holdings of three types of non-family firms in panel C of Table 17 and could not find a positive relationship between excess control rights and corporate cash holding in any of the three types of non-family firms ${ }^{20}$. Finally, we test the different corporate cash holdings in family and non-family firms using the propensity score matching method ${ }^{21}$ (results are reported in panel D of Table 17), and identify a statistically significant difference between corporate cash holdings in family and non-family firms with matched firm characteristics.

Overall, our results in Table 17 support our main argument and suggest that the ownership structure in family and non-family firms do not vary much, and the difference in the relationship between excess control rights and corporate cash holding in family and nonfamily firms is caused by family control rather than differences in the ownership structure.

$<$ Table 17>

\footnotetext{
${ }^{19}$ We find that $88 \%$ of family firms have excess control rights while the percentage in non-family controlled firms is $89 \%$, and the mean of excess control rights in family and non-family firms are both $10 \%$.

${ }^{20}$ We also examine the effect of excess control rights on inter-corporate loans, dividend and investment, the results are similar to the results that we have reported in Tables 3 and 4 . Results are not reported to save space.

${ }^{21}$ The variables we employ to match are contains excess control rights, controlling shareholders' control rights, firm size, leverage ratio, operation cash flow, operation cash flow volatility and industry and year fixed effects.
} 


\subsubsection{Other robustness tests}

Besides the results reported above, we also conduct a series of robustness tests, including: (1) following Harford et al. (2014), we first redo all our tests using the two-stage least-squares system of equations; (2) instead of our structural regression model, we re-conduct our regressions using the fixed effect of panel data and the OLS regression model; (3) instead of using the percentage of cash holding/inter-corporate loan that are scaled by firm size, we redo our main regressions using the natural logarithm of the amount of those values; (4) we define the post-NTS reform period as either until 2008 or until 2011; (5) we interact the excess control rights with firm size to control the size effect; and (6) we extend our definition of social and political connections to include the top executives (CEO and chairman). We found that our main results do not change based on those various robustness tests, and do not report them to save space.

\section{Conclusions}

This study investigates the effect of excess control rights on the cash holdings of family firms in China, using non-family firms as a controlling sample. We find that family firms with more excess control rights hold more cash and these high levels of cash are mainly tunneled by controlling shareholders rather than be invested or paid to shareholders as dividends. We also find that controlling shareholders' incentive to hold cash for tunneling in family firms depends on the degree of the agency problem between controlling and minority shareholders, i.e., it decrease markedly after the NTS reform which aligns the interests of controlling and minority shareholders, but it is enhanced by the presence of multiple large shareholders who often don't monitor the behavior of controlling shareholders (a collusion incentive). Moreover, the incentive for Chinese family firms to hold cash for tunneling is exacerbated by the one child policy and associated family succession problem, the political connections of 
the family founders and direct involvement by the family in management, but it is alleviated by the interpersonal trust of the founders.

We provide a great deal of additional evidence to support our main argument: for example, we find that controlling shareholders with more excess control rights hold more cash for tunneling when the listed firm is in a sound financial condition, and even when they have no need to hold a high levels of cash; we also show that the marginal value of high cash holdings in family firms with excess control rights is negative.

Overall, our results provide direct evidence that in emerging markets like China, due to the unique environmental opportunities and constraints that are different with the US, family firms with excess control rights tend to hold more cash for tunneling and these cash holdings are actually value destroying. Our findings further suggest that the corporate cash holding policy in Chinese family firms is driven by agency conflicts between controlling and minority shareholders and are shaped by the unique characteristics of Chinese family firms such as: the family succession problem arising from the unique government one-child policy, the importance of social and political connections, and the direct involvement of family in management. 


\section{Reference}

Acharya, V., Almeida, H., Campello, M., 2007. Is cash negative debt? A hedging perspective on corporate financial policies, Journal of Financial Intermediation 16, 515-554.

Aguilera, R.V., Filatotchev, I., Gospel, H. and Jackson, G., An organizational approach to comparative corporate governance: Costs, contingencies and complementarities, Organization Science, 19, 475-492.

Almeida, H., Campello, M., Cunha, I. and Weisbach, M. S., 2013, Corporate liquidity management: A conceptual framework and survey, working paper.

Al-Najjar, B., 2013, The financial determinants of corporate cash holdings: Evidence from some emerging markets, International Business Review, 22, 77-88.

Amit, R., Ding, T., Villalonga, B., Zhang, H., 2009. The role of institutional development in the prevalence and value of family firms, working paper.

Anderson, R. C., Reeb, D. M., 2003. Founding family ownership and firm performance: evidence from the S\&P 500, Journal of Finance 58, and 1301-1327.

Attig, N., Guedhami, O., Mishra, D., 2008. Multiple Large Shareholders, Control Contests, and Implied Cost of Equity, Journal of Corporate Finance 14, 721-737.

Bates, T. W., Kahle, K. M., Stulz, R. M., 2009. Why do U.S. firms hold so much more cash than they used to?, The Journal of Finance, 64, 1985-2021.

Beltratti, A., Bortolitti, B. and Casscvaio, M., 2011. Fiat privatization: the non-tradable share reform and stock market fundamentals in China. Working paper.

Berkman, H., Cole, R.A. and Fu, L.J., 2011, Political connections and minority-shareholder protection: Evidence from Securities-market regulation in China, Journal of Financial and Quantitative Analysis, 45, 1391-1417.

Bennedsen, M., Wolfenzon, D., 2000. The balance of power in closely held corporations, Journal of Financial Economics, 58, 113-139.

Bennedsen, M., Nielsen, K. Wolfenzon, D., 2007, The family behind the family firm: evidence from CEO transitions, working paper.

Bennedsen, M., Fan, J.P.H., Jian, M. and Yeh, Y., 2014, The family business map framework selective survey and evidence from Chinese family firms, Journal of Corporate Finance, forthcoming. 
Bolton, P., Von Thadden, E., 1998. Blocks, liquidity, and corporate control, Journal of Finance, 53 1-25.

Bunkanwanicha, P., Fan, J. P. H., Wiwattanakantang, Y., 2013. The value of marriage to family firms, Journal of Financial and Quantitative Analysis 48, 611-636.

Cao, J., Cumming, D. and Wang, X., 2014, One-child policy and family firms in China, Journal of Corporate Finance, forthcoming.

Chen, C.J., Li, Z., Su, X. and Sun, Z., 2011, Rent-seeking incentives, corporate political connections, and the control structure of private firms: Chinese evidence, Journal of Corporate Finance, vol.17, pp.229-243.

Chen, Q., Chen X., Schipper, K., Xu, Y., Xue, J., 2012. The sensitivity of corporate cash holdings to corporate governance, The Review of Financial Studies 25, 3610-3644.

Chen, I., Wang, B., 2014. Corporate governance and cash holdings: Empirical evidence from an emerging market, Working paper.

Cheung, Y.L., Rau, P.R., Stouraitis, A., 2006. Tunnelling, propping and expropriation: evidence from connected party transactions in Hong Kong, Journal of Financial Economics 82, 343-386.

Claessens, S., Djankov S., Lang H.P., 2000. The separation of ownership and control in east Asian corporation, Journal of Financial Economics 58, 81-112.

Claessens, S., Djankov, S., Fan, J. P. H., Lang, H. P., 2002. Disentangling the incentive and entrenchment effects of large shareholdings, Journal of Finance 57, 2741-2771.

Cornwell, C., Schmidt, P. and Wyhowski, D., 1992, Simultaneous equations and panel data, Journal of Econometrics, 51, 151-181.

Cronqvist, H., Nilsson, M., 2003, Agency costs of controlling minority shareholders, The Journal of Financial and Quantitative Analysis 38, 695-719.

Cull, R. and Xu, L., 2003, Who gets credit? The behaviour of bureaucrats and state banks in allocating credit to Chinese state-owned enterprises, Journal of Development Economics,71 (2), 533-559.

Denis, D. J., Sibilkov, V., 2010. Financial constraints, investment, and the value of cash holdings, The Review of Financial Studies 23, 247-269.

Dittmar, A., Mahrt-Smith, J., Servaes, H., 2003. International corporate governance and corporate cash holdings, Journal of Financial and Quantitative Analysis 38, 111-133.

Dittmar, A., Mahrt-Smith, J., 2007, Corporate governance and the value of cash holdings, Journal of Financial Economics 83, 599-634. 
Duchin, R., 2010. Cash holding and corporate diversification, The Journal of Finance 65, 955-992.

Faccio, M., Lang, L. H. P., Young, L., 2001. Dividends and expropriation, The American Economic Review 91, 54-78.

Faccio, M., Lang, H. P. L, 2002. The ultimate ownership of western European corporations, Journal of Financial Economics 65, 365-395.

Faccio, M., Lang, H. P. L., Young, L., 2010. Pyramiding vs leverage in corporate groups: international evidence, Journal of International Business Studies 41, 88-104.

Fan, J.P.H., Wang, T.J. and Zhang, T., 2007, Political connected CEOs, corporate governance, and Post-IPO performance of China's newly partially privatized firms, Journal of Financial Economics, 84, 330-357.

Firth, M., Lin, C., Liu, P., Wong, S.M.L., 2009, Inside the black box: bank credit allocation in China's private sector, Journal of Banking and Finance, 33 (6), 1144-1155.

Friedman, E., Johnson, S., Mitton, T., 2003. Propping and tunnelling, Journal of Comparative Economics 31, 732-750.

Gao, H., Harford, J., Li, K., 2013. Determinants of corporate cash policy: Insights from private firms, Journal of Finance Economics 109, 623-639.

Gedajlovic, E., Carney, M., Chrisman, J.J. and Kellermanns, F.W., The adolescence of family firm research taking stock and planning for the future, Journal of Management, 38, 10101037.

Gomez-Mejia L.R., Cruz, C., Berrone, P. and Castro, J.D., 2011, The bind that ties: Socioemotional wealth preservation in family firms, The Academy of Management Annals, 5, 653-707.

Harford, J., 1999. Corporate cash reserve and acquisitions, The Journal of Finance 54, 19691997.

Harford, J., Mansi, S. A., Maxwell, W. F., 2008. Corporate governance and corporate cash holdings in the US, Journal of Financial Economics 87, 353-555.

Harford, J., Klasa, S. and Maxwell, W.F., 2014, Refinancing risk and cash holdings, Journal of Finance, 69, 975-1012.

Jiang, G., Lee, C. M. C., Yue H., 2010. Tunneling through intercorporate loans: The China experience, Journal of Financial Economics 98, 1-20. 
Jiang, F., Jiang, Z., Kim, K.Z., Zhang, M., 2014. Family-firm risk-taking: does religion matter? Journal of Corporate Finance, forthcoming.

Kalcheva, I., Lins K. V., 2007. International evidence on cash holdings and expected managerial agency problems, Review of Financial Studies 20, 1087-1112.

Kim, C., Mauer, D. C., Sherman, A. E., 1998. The determinants of corporate liquidity: theory and evidence, Journal of Financial Economics 33, 315-335.

La Porta, R., Lopez-de-Silanes, F., Shleifer, A., 1999. Corporate ownership around the world, Journal of Finance 54, 471-517.

Larcker, D.F. and Rusticus, T.O., 2010, On the use of instrumental variables in accounting research, Journal of Accounting and Economics, 49, 186-205.

Lehman, E., Weigand, J., 2000. Does the governed corporation perform better? Governance structures and corporate performance in Germany, European Finance Review, 4, 157-195.

Lemmon, M. L., Lins, K. V., 2003. Ownership structure, corporate governance, and firm value: evidence from the East Asian Financial Crisis, The Journal of Finance 58, 1445-1468. Lin, C, Ma Y., Malatesta, P., Xuan, Y., 2012. Corporate ownership structure and bank loan syndicate structure, Journal of Financial Economics 101, 1-22.

Li, H. and Zhang, Y., 2007, The role of managers' political networking and functional experience in new venture performance: Evidence from China's transition economy, Strategic Management Journal, 28, 791-804.

Li, K., Yue, H., Zhao, L., 2009, Ownership, institutions, and capital structure: evidence from China, Journal of Comparative Economics, 37 (3), 471-490.

Liu, Q., Tian, G., 2012. Controlling shareholders expropriation and firm leverage decision: evidence from Chinese non-tradable share reform, Journal of Corporate Finance 18, 782803.

Liu, Q., Tang, J. and Tian, G., 2013, Does political capital create value in the IPO market? Evidence from China, Journal of Corporate Finance, 23, 395-413.

Luo, Y., 2003, Industrial dynamics and managerial networking in an emerging market: the case of China, Strategic Management Journal, 24(13), 1315-1327.

Maury, B., Pajuste, A., 2005. Multiple large shareholders and firm value, Journal of Banking and Finance, 29, 1813-1834.

Mehrotra, V., Morck, R., Shim, J. and Wiwattanakantang, Y., 2013, Adoptive expectations: Rising sons in Japanese family firms, Journal of Financial Economics, 108, 840-854. 
Myers, S., Majluf, N., 1984. Corporate financing and investment decisions when firms have information that investors do not have, Journal of Financial Economics 13, 187-221.

Myers, S. C., Rajan, R. G., 1998. The paradox of liquidity, The Quarterly Journal of Economics 113, 733-771.

Opler, T., Pinkowitz, L., Stulz, R., Williamson, R., 1999. The determinants and implications of corporate cash holdings, Journal of Financial Economics 52, 3-46.

Ozkan, A., Ozkan, N., 2004, Corporate cash holdings: An empirical investigation of UK companies, Journal of Banking and Finance 28, 2103-2134.

Peng, M.W. and Heath P.S., 1996, The growth of the firm in planned economies in transition: Institutions, organizations, and strategic choice, The Academy of Management Review, 21, 492-528.

Peng, W. Q., Wei, K.C. J., Yang, Z., 2011, Tunneling or propping: evidence from connected transaction in China, Journal of Corporate Finance 17, 306-325.

Pinkowitz, L., Stulz, R., Williamson, R., 2006. Does the contribution of corporates cash holdings and dividends to firm value depend on governance? Across-country analysis, The Journal of Finance 61, 2725-2751.

Riddick, L. A., Whited, T. M., 2009. The corporate propensity to save, The Journal of Finance 64, 1729-1766.

Qian, M., Pan, H. and Yeung, B., 2011, Expropriations of minority shareholders in politically connected firms, working paper.

Rousseau, P. L., Xiao, S., 2008. Change of control and the success of China's share-issue privatization, China Economic Review 19, 605-613.

Sanchez, J., Yurdagul, E., 2013. Why are corporations holding so much cash? The Regional Economist, Federal Reserve Bank of St. Louis, January 2013.

Shleifer, A. and Vishny, R. W., 1986. Large shareholders and corporate control, Journal of Political economy 94, 461-488.

Stacchini, M. and Degasperi, P., 2014, Trust, family business and financial intermediation. Journal of Corporate Finance, forthcoming.

Villalonga, B. and Amit, R., 2006. How do family ownership, control and management affect firm value?, Journal of Financial Economics 80, 385-417.

Xu, N., Yuan, Q., Jiang, X. and Chan, K.C., 2014, Founder's political connections, second generation involvement, and family firm performance: Evidence from China, Journal of Corporate Finance, forthcoming. 
Zellner, A. and Theil, H., 1962, Three-stage least square: Simultaneous estimation of simultaneous equations, Econometrica, 30, 54-78. 


\section{Tables}

Table 1 Descriptive statistics and univariate test

Panel A. Summary statistics. This panel presents the number of observations, mean, median, standard deviation (STD),

25\% percentile (P25) and 75\% percentile (P75).

\begin{tabular}{lcccccc}
\hline & \multicolumn{7}{c}{ Family Business } \\
\cline { 2 - 7 } VARIABLE & NO. & MEAN & MEDIAN & STD & P25 & P75 \\
\hline CASHTA & 1201 & 0.17 & 0.14 & 0.11 & 0.09 & 0.22 \\
EXCESS & 1201 & 0.1 & 0.09 & 0.08 & 0.03 & 0.16 \\
ORECTA & 1201 & 0.03 & 0.01 & 0.12 & 0.01 & 0.04 \\
TUNNELING RPT & 767 & 0.68 & 1 & 0.47 & 0 & 1 \\
CAPEXTA & 1201 & 0.05 & 0.04 & 0.05 & 0.02 & 0.07 \\
DIVTE & 1201 & 0.32 & 0.06 & 1.09 & 0 & 0.31 \\
CASHFLOW & 1201 & 0.22 & 0.21 & 0.13 & 0.12 & 0.29 \\
OPCFTA & 1201 & 0.04 & 0.05 & 0.09 & 0 & 0.09 \\
OPCF-SD & 1201 & 18.24 & 18.21 & 1.14 & 17.49 & 18.9 \\
SIZE & 1201 & 21.45 & 21.36 & 0.96 & 20.77 & 22.07 \\
LEVERAGE & 1201 & 0.6 & 0.6 & 0.21 & 0.47 & 0.74 \\
DIVDUMMY & 1201 & 0.54 & 1 & 0.5 & 0 & 1 \\
M2B & 1201 & 4.08 & 3.06 & 7 & 1.96 & 4.95 \\
ROA & 1201 & 0.04 & 0.04 & 0.05 & 0.01 & 0.06 \\
SEO & 1201 & 0.1 & 0 & 0.3 & 0 & 0 \\
BOARDIND & 1201 & 0.36 & 0.33 & 0.05 & 0.33 & 0.38 \\
DUALITY & 1201 & 0.17 & 0 & 0.38 & 0 & 0 \\
SECONDLARGE & 1201 & 0.6 & 1 & 0.49 & 0 & 1 \\
FIM & 1201 & 0.62 & 1 & 0.49 & 0 & 1 \\
\hline
\end{tabular}

Panel B Univariate test of main dependent variables in family firms with low and high excess control right

This table presents the univariate test of main dependent variables for firms with low and high excess control rights in family firms. 'Low excess' and 'High excess' refers to firms with excess control rights lower or higher than median. 'Difference tests' columns report both $\mathrm{t}$ value for T-test and $\mathrm{z}$ value for Wilcoxon test of difference in mean and median. ${ }^{*}$ and $* * *$ represent significant at $10 \%$ and $1 \%$ level significance.

\begin{tabular}{cccccccc}
\hline & & \multicolumn{2}{c}{ High excess } & \multicolumn{2}{c}{ Low excess } & \multicolumn{2}{c}{ Difference tests } \\
\cline { 3 - 8 } & No. & Mean & Median & Mean & Median & T value & Z value \\
\hline CASHTA & 1201 & 0.17 & 0.15 & 0.16 & 0.13 & $0.01^{*}$ & $0.02^{* *}$ \\
ORECTA & 1201 & 0.04 & 0.02 & 0.03 & 0.01 & $0.01^{*}$ & $0.01^{*}$ \\
TUNNELING & 757 & 0.69 & 1 & 0.54 & 1 & $0.15^{* * *}$ & 0.00 \\
\hline
\end{tabular}


Panel C Difference in difference test for corporate cash holdings in family firms with and without excess control rights

This table presents univariate tests of cash holding in firms high and low level of excess control rights and in different group of firms. Before NTS reform and After NTS reform refer to firm year observations before and after the NTS reform. SECONDLARGE, ONECHILD, DESCENDENT, SOCIAL TRUST, POLITICAL, FAMILYCEO refer to firms who have these characteristics; Non-SECONDLARGE, Non-ONECHILD, Non-DESCENDENT, NonSOCIAL TRUST, Non-POLITICAL and Non-FAMILYCEO represent firms who do not have these characteristics. 'Low excess' and 'High excess' refers to firms with excess control rights lower or higher than median. 'Difference tests' columns report the difference in mean and median. *, **, *** represent significant of both $\mathrm{T}$ value for mean and $\mathrm{Z}$ value of median at $10 \%, 5 \%$ and $1 \%$ level significance.

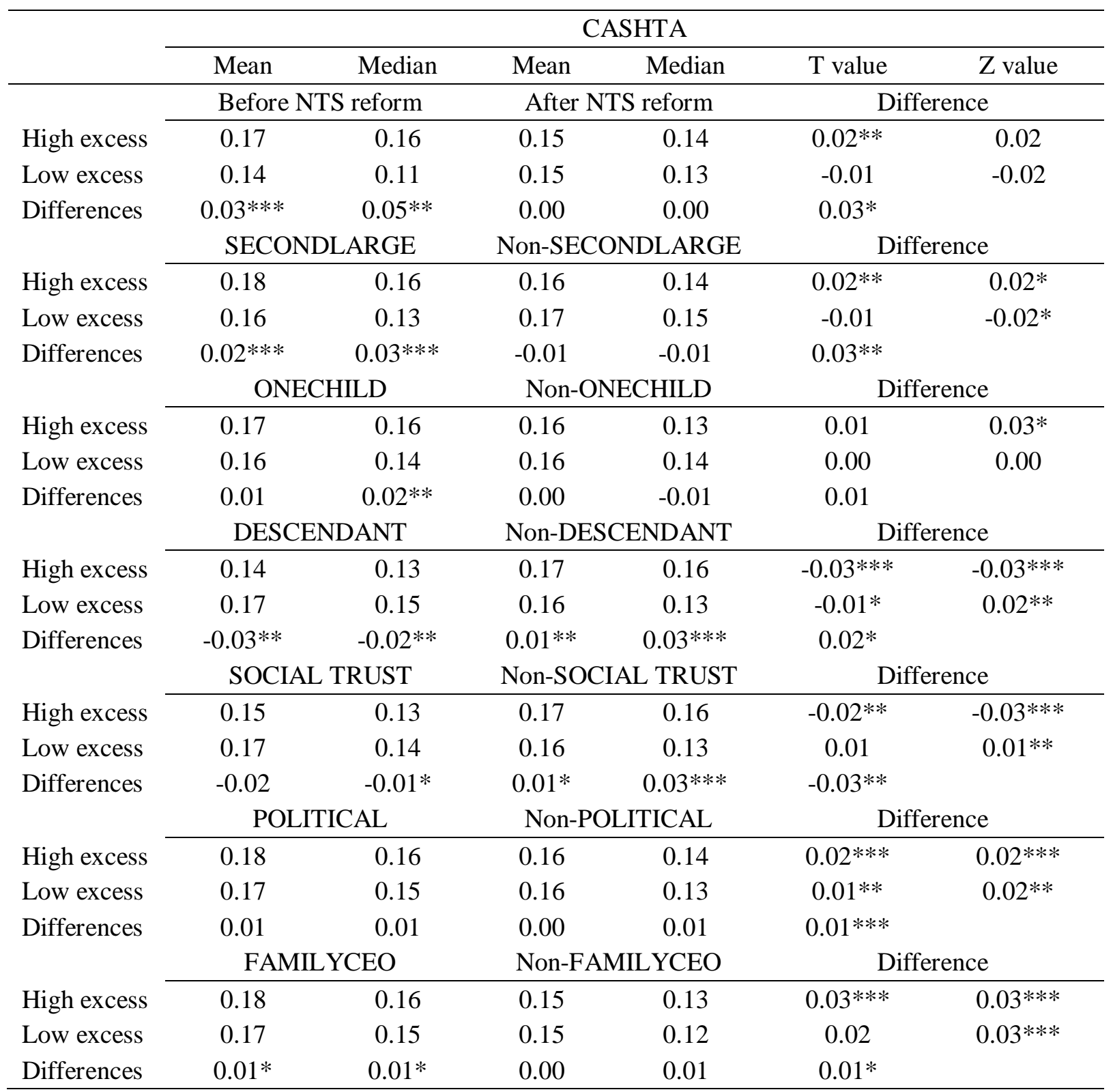


Panel D Difference in difference test for inter-corporate loans in family firms with and without excess control rights

This table presents univariate tests of inter-corporate loans in firms high and low level of excess control rights and in different group of firms. Before NTS reform and After NTS reform refer to firm year observations before and after the NTS reform. SECONDLARGE, ONECHILD, DESCENDENT, SOCIAL TRUST, POLITICAL, FAMILYCEO refer to firms who have these characteristics; Non-SECONDLARGE, Non-ONECHILD, NonDESCENDENT, Non-SOCIAL TRUST, Non-POLITICAL and Non-FAMILYCEO represent firms who do not have these characteristics. 'Low excess' and 'High excess' refers to firms with excess control rights lower or higher than median. 'Difference tests' columns report the difference in mean and median. *, **, *** represent significant of both $\mathrm{T}$ value for mean and $\mathrm{Z}$ value of median at $10 \%, 5 \%$ and $1 \%$ level significance.

\begin{tabular}{|c|c|c|c|c|c|c|}
\hline & \multicolumn{6}{|c|}{ ORECTA } \\
\hline & Mean & Median & Mean & Median & T value & $\mathrm{Z}$ value \\
\hline & \multicolumn{2}{|c|}{ Before NTS reform } & \multicolumn{2}{|c|}{ After NTS reform } & \multicolumn{2}{|c|}{ Difference } \\
\hline High excess & 0.1 & 0.03 & 0.03 & 0.02 & $0.07 * * *$ & $0.01 * * *$ \\
\hline Low excess & 0.03 & 0.02 & 0.03 & 0.02 & $0.00-$ & $0.00-$ \\
\hline \multirow[t]{2}{*}{ Differences } & $0.07 *$ & $0.01 * * *$ & $0.00 *$ & 0.00 & $-0.07 * * *$ & \\
\hline & \multicolumn{2}{|c|}{ SECONDLARGE } & \multicolumn{2}{|c|}{ Non-SECONDLARGE } & \multicolumn{2}{|c|}{ Difference } \\
\hline High excess & 0.05 & 0.02 & 0.03 & 0.01 & $0.02 *$ & $0.01 *$ \\
\hline Low excess & 0.03 & 0.01 & 0.03 & 0.01 & 0.00 & 0.00 \\
\hline \multirow[t]{2}{*}{ Differences } & $0.02 *$ & $0.01^{*}$ & 0.00 & 0.00 & $0.02 *$ & \\
\hline & \multicolumn{2}{|c|}{ ONECHILD } & \multicolumn{2}{|c|}{ Non-ONECHILD } & \multicolumn{2}{|c|}{ Difference } \\
\hline High excess & 0.05 & 0.02 & 0.02 & 0.01 & $0.03^{*}$ & $0.01^{* * *}$ \\
\hline Low excess & 0.03 & 0.01 & 0.02 & 0.01 & 0.01 & 0.00 \\
\hline \multirow[t]{2}{*}{ Differences } & $0.02 *$ & $0.01 * * *$ & 0.00 & 0.00 & $0.02 *$ & \\
\hline & \multicolumn{2}{|c|}{ DESCENDANT } & \multicolumn{2}{|c|}{ Non-DESCENDANT } & \multicolumn{2}{|c|}{ Difference } \\
\hline High excess & 0.02 & 0.01 & 0.04 & 0.02 & -0.02 & $-0.01^{* * *}$ \\
\hline Low excess & 0.03 & 0.01 & 0.03 & 0.01 & 0.00 & 0.00 \\
\hline \multirow[t]{2}{*}{ Differences } & -0.01 & 0.00 & $0.01 *$ & $0.01 * * *$ & $-0.02 *$ & \\
\hline & \multicolumn{2}{|c|}{ SOCIAL TRUST } & \multicolumn{2}{|c|}{ Non-SOCIAL TRUST } & \multicolumn{2}{|c|}{ Difference } \\
\hline High excess & 0.03 & 0.02 & 0.04 & 0.02 & -0.01 & 0.00 \\
\hline Low excess & 0.02 & 0.01 & 0.03 & 0.02 & $-0.01^{*}$ & $-0.01 * * *$ \\
\hline \multirow[t]{2}{*}{ Differences } & 0.01 & $0.01 * * *$ & $0.01^{*}$ & 0.00 & 0.00 & \\
\hline & \multicolumn{2}{|c|}{ POLITICAL } & \multicolumn{2}{|c|}{ Non-POLITICAL } & \multicolumn{2}{|c|}{ Difference } \\
\hline High excess & 0.05 & 0.02 & 0.03 & 0.01 & $0.02 * *$ & 0.01 \\
\hline Low excess & 0.03 & 0.01 & 0.03 & 0.01 & 0.00 & $0.00 * *$ \\
\hline \multirow[t]{2}{*}{ Differences } & $0.02 *$ & $0.01 * * *$ & 0.00 & 0.00 & $0.02^{* * *}$ & \\
\hline & \multicolumn{2}{|c|}{ FAMILYCEO } & \multicolumn{2}{|c|}{ Non-FAMIL YCEO } & \multicolumn{2}{|c|}{ Difference } \\
\hline High excess & 0.04 & 0.02 & 0.03 & 0.02 & $0.01 *$ & 0.00 \\
\hline Low excess & 0.03 & 0.01 & 0.03 & 0.01 & 0.00 & 0.00 \\
\hline Differences & $0.01 *$ & 0.01 & 0.00 & $0.01^{*}$ & $0.01^{* *}$ & \\
\hline
\end{tabular}


Table 2 The effect of excess control rights on corporate cash holdings: 3SLS regression results with accounting for endogeneity issue of cash holding and other corporate policy variables

This table presents the structural simultaneous regression results on the effect of excess control rights on corporate cash holdings. Endogeneous variables include: corporate cash holding, leverage, dividend payout ratio, and debt maturity. 3SLS approach is used to address the endogeneity issue. Results of family firms reported in column 2, results of full sample and non-family firms in columns 1 and 3.Definition of variables are detailed in Appendix A. Standardized beta coefficients; p-values in parentheses. *, **, *** represent significant at $10 \%, 5 \%$ and $1 \%$ level significance respectively.

\begin{tabular}{|c|c|c|c|}
\hline & $\begin{array}{c}\text { ALL } \\
\text { CASHTA }\end{array}$ & $\begin{array}{l}\text { FAMILY } \\
\text { CASHTA }\end{array}$ & $\begin{array}{c}\text { Non-FAMILY } \\
\text { CASHTA }\end{array}$ \\
\hline \multirow{2}{*}{ EXCESS } & 0.04 & $0.09 * *$ & -0.01 \\
\hline & $(0.15)$ & $(0.03)$ & $(0.75)$ \\
\hline \multirow[t]{2}{*}{ CASHFLOW } & 0.01 & 0.04 & -0.05 \\
\hline & $(0.53)$ & $(0.10)$ & $(0.10)$ \\
\hline \multirow[t]{2}{*}{ BOARDIND } & 0.03 & 0.03 & 0.02 \\
\hline & $(0.50)$ & $(0.62)$ & $(0.79)$ \\
\hline \multirow[t]{2}{*}{ DUALITY } & -0.00 & -0.01 & -0.00 \\
\hline & $(0.61)$ & $(0.23)$ & $(0.56)$ \\
\hline \multirow[t]{2}{*}{ SECONDLARGE } & $0.01 * *$ & $0.01 * *$ & 0.00 \\
\hline & $(0.02)$ & $(0.03)$ & $(0.69)$ \\
\hline \multirow[t]{2}{*}{ LEVERAGE } & $-0.22 * * *$ & $-0.15^{* * *}$ & -0.04 \\
\hline & $(0.00)$ & $(0.01)$ & $(0.43)$ \\
\hline \multirow[t]{2}{*}{ DIVTE } & $-0.17 * * *$ & $-0.29 * * *$ & $0.43^{* * *}$ \\
\hline & $(0.00)$ & $(0.00)$ & $(0.00)$ \\
\hline \multirow[t]{2}{*}{ DEBT MATURITY } & $0.10^{* * *}$ & $0.12^{* * *}$ & $-0.11 * * *$ \\
\hline & $(0.00)$ & $(0.00)$ & $(0.00)$ \\
\hline \multirow[t]{2}{*}{ OPCF-SD } & 0.00 & 0.00 & -0.00 \\
\hline & $(0.17)$ & $(0.74)$ & $(0.50)$ \\
\hline \multirow[t]{2}{*}{ SIZE } & $0.02 * * *$ & $0.02 * * *$ & $-0.03 * * *$ \\
\hline & $(0.00)$ & $(0.00)$ & $(0.00)$ \\
\hline \multirow[t]{2}{*}{ OPCFTA } & $0.20 * * *$ & $0.09 * * *$ & 0.04 \\
\hline & $(0.00)$ & $(0.01)$ & $(0.45)$ \\
\hline \multirow[t]{2}{*}{ M2B } & -0.00 & -0.00 & 0.00 \\
\hline & $(0.47)$ & $(0.11)$ & $(0.14)$ \\
\hline \multirow[t]{2}{*}{ SEO } & $0.05^{* * *}$ & $0.02 * * *$ & 0.02 \\
\hline & $(0.00)$ & $(0.01)$ & $(0.21)$ \\
\hline \multirow[t]{2}{*}{ INTERCEPT } & $-0.33 * * *$ & $-0.25^{*}$ & $0.83 * * *$ \\
\hline & $(0.00)$ & $(0.05)$ & $(0.00)$ \\
\hline YEAR & YES & YES & YES \\
\hline INDUSTRY & YES & YES & YES \\
\hline $\mathrm{N}$ & 2180 & 1201 & 982 \\
\hline
\end{tabular}


Table 3 The effect of excess control rights and high corporate cash holding on inter-corporate loans: 3SLS regression results with accounting for endogeneity issue of inter-corporate loans, cash holding and other corporate policy variables

The dependent variable (ORECTA) is inter-corporate loans to controlling shareholders. 3SLS approach is used to address the endogeneity issue of corporate policy variables include inter-corporate loan, high cash holding dummy, leverage and dividend payout ratio. Results of family firms reported in columns 1-2, results of non-family firms in columns 3-4. Definition of variables are detailed in Appendix A. Standardized beta coefficients; p-values in parentheses. *, **, *** represent significant at $10 \%, 5 \%$ and $1 \%$ level significance respectively.

\begin{tabular}{|c|c|c|c|c|}
\hline \multirow{3}{*}{$\begin{array}{l}\text { EXCESS } \\
\end{array}$} & \multicolumn{4}{|c|}{ ORECTA } \\
\hline & \multicolumn{2}{|c|}{ FAMILY } & \multicolumn{2}{|c|}{ Non-FAMILY } \\
\hline & $0.13^{* * *}$ & -0.05 & $0.07^{* * *}$ & $0.06^{* *}$ \\
\hline & $(0.01)$ & $(0.51)$ & $(0.00)$ & $(0.05)$ \\
\hline \multirow[t]{2}{*}{ HCASHM } & $0.04^{* * *}$ & $0.09 * * *$ & $0.03^{* * *}$ & $0.03^{* * *}$ \\
\hline & $(0.00)$ & $(0.00)$ & $(0.00)$ & $(0.00)$ \\
\hline \multirow[t]{2}{*}{ HCASHM*EXCESS } & & $0.45^{* * *}$ & & 0.04 \\
\hline & & $(0.00)$ & & $(0.44)$ \\
\hline \multirow[t]{2}{*}{ CASHFLOW } & -0.01 & -0.01 & -0.02 & -0.02 \\
\hline & $(0.78)$ & $(0.81)$ & $(0.16)$ & $(0.16)$ \\
\hline \multirow[t]{2}{*}{ BOARDIND } & $0.14^{*}$ & $0.12 *$ & -0.04 & -0.04 \\
\hline & $(0.05)$ & $(0.09)$ & $(0.17)$ & $(0.18)$ \\
\hline \multirow[t]{2}{*}{ DUALITY } & $0.03^{* * *}$ & $0.03^{* * *}$ & 0.00 & 0.00 \\
\hline & $(0.00)$ & $(0.00)$ & $(0.48)$ & $(0.42)$ \\
\hline \multirow[t]{2}{*}{ SECONDLARGE } & 0.01 & 0.01 & $-0.01 * * *$ & $-0.01^{* * *}$ \\
\hline & $(0.22)$ & $(0.38)$ & $(0.00)$ & $(0.00)$ \\
\hline \multirow{2}{*}{ LEVERAGE } & $0.18^{* * *}$ & $0.19 * * *$ & $0.13^{* * *}$ & $0.13^{* * *}$ \\
\hline & $(0.01)$ & $(0.01)$ & $(0.00)$ & $(0.00)$ \\
\hline \multirow[t]{2}{*}{ SIZE } & $-0.02 * * *$ & $-0.02^{* * *}$ & $-0.02 * * *$ & $-0.02^{* * *}$ \\
\hline & $(0.00)$ & $(0.00)$ & $(0.00)$ & $(0.00)$ \\
\hline \multirow[t]{2}{*}{ OPCFTA } & -0.04 & -0.03 & -0.01 & -0.01 \\
\hline & $(0.35)$ & $(0.50)$ & $(0.65)$ & $(0.56)$ \\
\hline \multirow[t]{2}{*}{ ROA } & $0.21^{* *}$ & $0.24 * *$ & $0.12^{* *}$ & $0.12^{* *}$ \\
\hline & $(0.04)$ & $(0.02)$ & $(0.03)$ & $(0.03)$ \\
\hline \multirow[t]{2}{*}{ INTERCEPT } & $0.34^{* * *}$ & $0.35 * * *$ & $0.34^{* * *}$ & $0.33^{* * *}$ \\
\hline & $(0.00)$ & $(0.00)$ & $(0.00)$ & $(0.00)$ \\
\hline SUM TEST & & $0.40 * * *$ & & $0.10^{* * *}$ \\
\hline EXCESS+HCASHM*EXCESS & & $(0.00)$ & & $(0.01)$ \\
\hline YEAR & YES & YES & YES & YES \\
\hline INDUSTRY & YES & YES & YES & YES \\
\hline $\mathrm{N}$ & 1201 & 1201 & 982 & 982 \\
\hline
\end{tabular}


Table 4 The effect of excess control rights and high corporate cash holding on capital expenditure/dividend: 3SLS regression results with accounting for endogeneity issue of capital expenditure (dividend payouts), cash holding and other corporate policy variables

The dependent variable of panel A is CAPEXTA, which is defined as the ratio of capital expenditures to total assets. The dependent variable of panel B is DIVTE, which is defined as the ratio of dividend payments to earnings. 3SLS approach is used to address the endogeneity issue of corporate policy variables. Results of family firms reported in columns 1-2, results of non-family firms in columns 3-4. Definition of variables are detailed in Appendix A. Standardized beta coefficients; p-values in parentheses. ${ }^{*}, * *, * * *$ represent significant at $10 \%, 5 \%$ and $1 \%$ level significance respectively.

Panel A Capital expenditure as dependent variable

\begin{tabular}{|c|c|c|c|c|}
\hline \multirow{3}{*}{$\begin{array}{l}\text { EXCESS } \\
\end{array}$} & \multicolumn{4}{|c|}{ CAPEXTA } \\
\hline & \multicolumn{2}{|c|}{ FAMILY } & \multicolumn{2}{|c|}{ Non-FAMILY } \\
\hline & $-0.06 * * *$ & 0.01 & $-0.04^{*}$ & $-0.08 * *$ \\
\hline & $(0.00)$ & (0.99) & $(0.10)$ & $(0.02)$ \\
\hline \multirow[t]{2}{*}{ HCASHM } & 0.00 & $0.03 * * *$ & $-0.02 * * *$ & $-0.03 * * *$ \\
\hline & $(0.51)$ & $(0.01)$ & $(0.00)$ & $(0.00)$ \\
\hline \multirow[t]{2}{*}{ HCASHM*EXCESS } & & $-0.15 * * *$ & & $0.11^{*}$ \\
\hline & & $(0.01)$ & & $(0.06)$ \\
\hline \multirow[t]{2}{*}{ CASHFLOW } & 0.02 & 0.02 & 0.00 & 0.00 \\
\hline & $(0.22)$ & $(0.20)$ & $(0.75)$ & $(0.86)$ \\
\hline \multirow[t]{2}{*}{ BOARDIND } & -0.04 & -0.04 & -0.01 & -0.01 \\
\hline & $(0.16)$ & $(0.20)$ & $(0.74)$ & $(0.68)$ \\
\hline \multirow[t]{2}{*}{ DUALITY } & $0.01 *$ & 0.01 & -0.00 & -0.00 \\
\hline & $(0.06)$ & $(0.11)$ & $(0.62)$ & $(0.75)$ \\
\hline \multirow[t]{2}{*}{ SECONDLARGE } & $-0.00 *$ & -0.00 & $0.01 *$ & $0.01 *$ \\
\hline & $(0.10)$ & $(0.14)$ & $(0.07)$ & $(0.07)$ \\
\hline \multirow[t]{2}{*}{ LEVERAGE } & $-0.09 * * *$ & $-0.12 * * *$ & 0.02 & 0.01 \\
\hline & $(0.00)$ & $(0.00)$ & $(0.68)$ & $(0.78)$ \\
\hline \multirow[t]{2}{*}{ SIZE } & $0.01 * * *$ & $0.01 * * *$ & $0.01^{*}$ & $0.01 *$ \\
\hline & $(0.00)$ & $(0.00)$ & $(0.06)$ & $(0.06)$ \\
\hline \multirow[t]{2}{*}{ OPCFTA } & $0.07 * * *$ & $0.06 * * *$ & $0.08^{* * *}$ & $0.08^{* * *}$ \\
\hline & $(0.00)$ & $(0.00)$ & $(0.00)$ & $(0.00)$ \\
\hline \multirow[t]{2}{*}{ ROA } & -0.02 & -0.05 & 0.11 & 0.10 \\
\hline & $(0.66)$ & $(0.27)$ & $(0.11)$ & $(0.15)$ \\
\hline \multirow[t]{2}{*}{ INTERCEPT } & -0.04 & -0.05 & -0.07 & -0.06 \\
\hline & $(0.26)$ & $(0.15)$ & $(0.21)$ & $(0.27)$ \\
\hline SUM TEST & & $-0.14^{* * *}$ & & 0.03 \\
\hline EXCESS+HCASHM*EXCESS & & $(0.00)$ & & $(0.47)$ \\
\hline YEAR & YES & YES & YES & YES \\
\hline INDUSTRY & YES & YES & YES & YES \\
\hline $\mathrm{N}$ & 1201 & 1201 & 982 & 982 \\
\hline
\end{tabular}




\begin{tabular}{|c|c|c|c|c|}
\hline \multirow{3}{*}{$\begin{array}{l}\text { EXCESS } \\
\end{array}$} & \multicolumn{4}{|c|}{ DIVTE } \\
\hline & \multicolumn{2}{|c|}{ FAMILY } & \multicolumn{2}{|c|}{ Non-FAMILY } \\
\hline & 0.22 & $1.46^{* * *}$ & 0.04 & 0.07 \\
\hline & $(0.24)$ & $(0.00)$ & $(0.56)$ & $(0.53)$ \\
\hline \multirow[t]{2}{*}{ HCASHM } & $-0.12^{* *}$ & $0.18^{*}$ & $0.32 * * *$ & $0.31^{* * *}$ \\
\hline & $(0.02)$ & $(0.09)$ & $(0.00)$ & $(0.00)$ \\
\hline \multirow[t]{2}{*}{ HCASHM*EXCESS } & & $-3.01 * * *$ & & -0.12 \\
\hline & & $(0.00)$ & & $(0.40)$ \\
\hline \multirow[t]{2}{*}{ CASHFLOW } & 0.12 & 0.10 & 0.03 & 0.03 \\
\hline & $(0.31)$ & $(0.44)$ & $(0.29)$ & $(0.40)$ \\
\hline \multirow[t]{2}{*}{ BOARDIND } & -0.42 & -0.28 & $-0.42 * *$ & $-0.45^{* *}$ \\
\hline & $(0.21)$ & (0.39) & $(0.05)$ & $(0.03)$ \\
\hline \multirow[t]{2}{*}{ DUALITY } & $-0.14 * * *$ & $-0.15^{* * *}$ & 0.03 & 0.03 \\
\hline & $(0.00)$ & $(0.00)$ & $(0.35)$ & $(0.38)$ \\
\hline \multirow[t]{2}{*}{ SECONDLARGE } & 0.05 & $0.07 *$ & $-0.06^{* * *}$ & $-0.06^{* * *}$ \\
\hline & $(0.17)$ & $(0.06)$ & $(0.00)$ & $(0.00)$ \\
\hline \multirow[t]{2}{*}{ LEVERAGE } & $-0.62 * *$ & $-0.71^{* *}$ & $-0.41^{*}$ & -0.33 \\
\hline & $(0.05)$ & $(0.03)$ & $(0.09)$ & $(0.16)$ \\
\hline \multirow[t]{2}{*}{ SIZE } & $0.06^{* * *}$ & $0.06 * *$ & $0.03^{*}$ & 0.02 \\
\hline & $(0.01)$ & $(0.01)$ & $(0.07)$ & $(0.12)$ \\
\hline \multirow{2}{*}{ OPCFTA } & -0.07 & -0.14 & $0.22 *$ & $0.24^{*}$ \\
\hline & $(0.71)$ & $(0.45)$ & $(0.10)$ & $(0.06)$ \\
\hline \multirow[t]{2}{*}{ ROA } & $-1.99 * * *$ & $-1.94 * * *$ & -0.53 & -0.44 \\
\hline & $(0.00)$ & $(0.00)$ & $(0.13)$ & $(0.19)$ \\
\hline \multirow[t]{2}{*}{ INTERCEPT } & -0.47 & -0.55 & -0.07 & -0.00 \\
\hline & $(0.23)$ & $(0.17)$ & $(0.79)$ & $(0.99)$ \\
\hline SUM TEST & & $-1.55^{* * *}$ & & -0.05 \\
\hline EXCESS+HCASHM*EXCESS & & $(0.00)$ & & $(0.37)$ \\
\hline YEAR & YES & YES & YES & YES \\
\hline INDUSTRY & YES & YES & YES & YES \\
\hline $\mathrm{N}$ & 1201 & 1201 & 982 & 982 \\
\hline
\end{tabular}


Table 5 The effect of excess control rights on tunneling, investment and dividend in family firms with high and low level of cash holding: 3SLS regression results with accounting for endogeneity issue of inter-corporate loans (cash holding) and other corporate policy variables

The dependent variables are ORECTA, CAPEXTA DIVTE as defined in appendix A. 3SLS approach is used to address the endogeneity issue of corporate policy variables. LOW and HIGH refer to subsample of firms with low and high level of cash holding. Results for non-family firms are not reported to save space. Definition of variables are detailed in Appendix A. Standardized beta coefficients; p-values in parentheses. *, ${ }^{* *}, * * *$ represent significant at $10 \%, 5 \%$ and $1 \%$ level significance respectively.

\begin{tabular}{lcccccc}
\hline & \multicolumn{2}{c}{ ORECTA } & \multicolumn{2}{c}{ CAPEXTA } & \multicolumn{2}{c}{ DIVTE } \\
\cline { 2 - 7 } EXCESS & HOW & HIGH & LOW & HIGH & LOW & HIGH \\
CASHFLOW & 0.03 & $0.15^{*}$ & -0.05 & $-0.09^{* * *}$ & 0.26 & 0.23 \\
& $(0.47)$ & $(0.09)$ & $(0.16)$ & $(0.00)$ & $(0.52)$ & $(0.43)$ \\
BOARDIND & 0.01 & -0.02 & 0.00 & 0.02 & -0.03 & 0.02 \\
& $(0.48)$ & $(0.68)$ & $(0.98)$ & $(0.35)$ & $(0.90)$ & $(0.93)$ \\
DUALITY & 0.01 & 0.05 & -0.03 & -0.06 & -0.42 & -0.35 \\
& $(0.89)$ & $(0.68)$ & $(0.55)$ & $(0.17)$ & $(0.56)$ & $(0.41)$ \\
SECONDLARGE & 0.00 & $0.04^{* *}$ & 0.01 & $0.01^{*}$ & -0.10 & $-0.14^{* *}$ \\
& $(0.99)$ & $(0.02)$ & $(0.47)$ & $(0.08)$ & $(0.28)$ & $(0.01)$ \\
LEVERAGE & -0.00 & 0.00 & -0.00 & $-0.01^{* *}$ & 0.04 & 0.02 \\
\multirow{3}{*}{ SIZE } & $(0.86)$ & $(0.73)$ & $(0.86)$ & $(0.02)$ & $(0.49)$ & $(0.69)$ \\
& 0.13 & 0.08 & -0.04 & $-0.12^{* * *}$ & -0.35 & $-1.03^{* * *}$ \\
OPCFTA & $(0.20)$ & $(0.49)$ & $(0.64)$ & $(0.00)$ & $(0.72)$ & $(0.01)$ \\
& -0.00 & $-0.03^{* * *}$ & 0.01 & $0.01^{* * *}$ & 0.06 & $0.05^{*}$ \\
ROA & $(0.95)$ & $(0.00)$ & $(0.24)$ & $(0.00)$ & $(0.44)$ & $(0.08)$ \\
& -0.02 & -0.14 & $0.07 * *$ & 0.01 & -0.23 & $-0.62^{* *}$ \\
INTERCEPT & $(0.61)$ & $(0.10)$ & $(0.04)$ & $(0.79)$ & $(0.61)$ & $(0.03)$ \\
& -0.08 & 0.32 & 0.04 & -0.08 & -0.62 & $-1.43^{* *}$ \\
\hline YEAR & $(0.39)$ & $(0.14)$ & $(0.58)$ & $(0.27)$ & $(0.45)$ & $(0.04)$ \\
INDUSTRY & -0.01 & $0.57^{* * *}$ & -0.02 & 0.03 & -0.61 & 0.18 \\
N & $(0.92)$ & $(0.00)$ & $(0.73)$ & $(0.51)$ & $(0.49)$ & $(0.72)$ \\
\hline
\end{tabular}


Table 6 The effect of excess control rights on tunneling: tunneling RPTs as proxy of tunneling

Dependent variable is a dummy variable equals to 1 if the firm has RPT in a particular year and the RPT is tunneling related and 0 if the firm has RPT but it is not tunneling related, so our sample size is smaller because only firm-year observations that have RPTs are included. 3SLS approach is used to address the endogeneity issue of corporate policy variables. Columns 1-2 and columns 3-4 report the interaction effect of high cash holding and excess control rights on tunneling RPT in family firms and non-family firms respectively; Columns 5-6 report the effect of excess control rights on tunneling RPT of family firms with low and high level of cash holding; Columns 7-8 report the effect of excess control rights on tunneling RPT of non-family firms with low and high level of cash holding. Definition of variables are detailed in Appendix A. Standardized beta coefficients; p-values in parentheses. ${ }^{*}, * *, * * *$ represent significant at $10 \%, 5 \%$ and $1 \%$ level significance respectively.

TUNNELING RPT

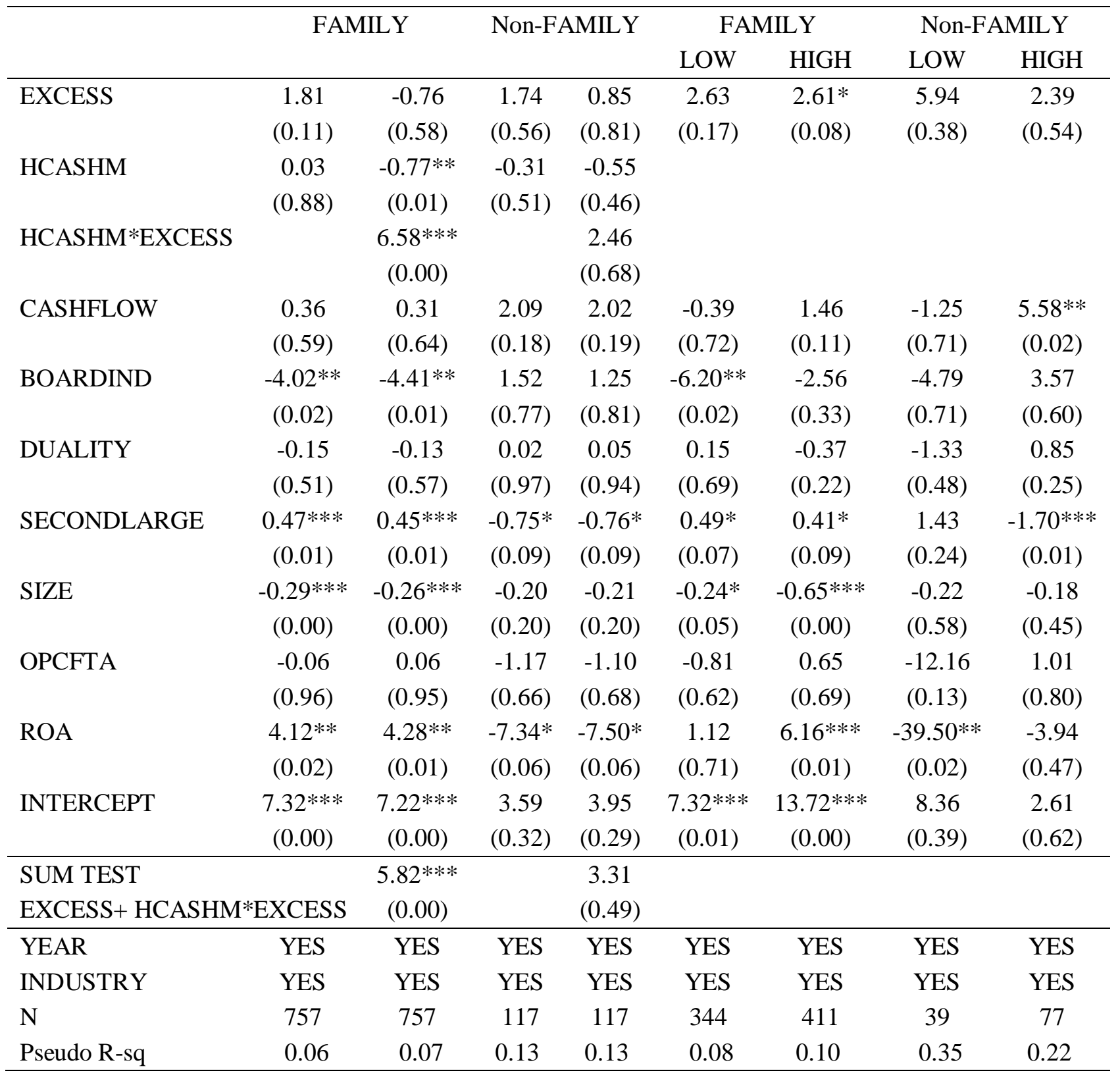


Table 7 The effect of excess control rights and NTS reform on corporate cash holdings/tunneling: 3SLS regression results with accounting for endogeneity issue of intercorporate loans (cash holding) and other corporate policy variables

Panel A report the results using corporate cash holding as dependent variables, panel B reports the results using inter-corporate loan to total assets as dependent variables. 3SLS approach is used to address the endogeneity issue of corporate policy variables. The results of family firms and nonfamily firms are reported in columns 1-2, and 3-4 respectively. REFORM is defined as a dummy equals to 1 if the firm year observation is in the period of 3 years after the reform was completed and 0 if the observation is in the period from 2004 to the year the reform was started. The sample size is smaller because the REFORM dummy is defined within a shorter period. Control variables for panel A include: CASHFLOW, BOARDIND, DUALITY, SECONDLARGE, LEVERAGE, DIVTE, OPCF-SD, SIZE, OPCFTA, M2B, SEO and DEBT MATURITY. Controlling variables for panel B include: CASHFLOW, BOARDIND, DUALITY, SECONDLARGE, LEVERAGE, SIZE, OPCFTA, and ROA. The coefficients of control variables are not reported to save space. Definition of variables are detailed in Appendix A. Standardized beta coefficients; p-values in parentheses. *, **, *** represent significant at $10 \%, 5 \%$ and $1 \%$ level significance respectively.

Panel A Corporate cash holding as dependent variable

\begin{tabular}{lcccc}
\hline & \multicolumn{2}{c}{ FAMILY } & \multicolumn{2}{c}{ Non-FAMILY } \\
& CASHTA & CASHTA & CASHTA & CASHTA \\
\hline EXCESS & $0.11^{* *}$ & $0.24^{* * *}$ & 0.03 & 0.02 \\
& $(0.03)$ & $(0.00)$ & $(0.59)$ & $(0.74)$ \\
REFORM & $-0.02^{* *}$ & 0.00 & -0.01 & -0.01 \\
& $(0.03)$ & $(0.91)$ & $(0.44)$ & $(0.48)$ \\
REFORM*EXCESS & & $-0.18^{* *}$ & & 0.01 \\
& & $(0.04)$ & & $(0.88)$ \\
\hline SUM TEST & & 0.06 & & 0.03 \\
EXCESS+REFORM*ECESS & & $(0.33)$ & & $(0.59)$ \\
\hline YEAR & YES & YES & YES & YES \\
INDUSTRY & YES & YES & YES & YES \\
N & 627 & 627 & 625 & 625 \\
\hline
\end{tabular}

Panel B Controlling shareholders' tunneling as dependent variable

\begin{tabular}{lcccc}
\hline & \multicolumn{2}{c}{ FAMILY } & \multicolumn{2}{c}{ Non-FAMILY } \\
& ORECTA & ORECTA & ORECTA & ORECTA \\
\hline EXCESS & $0.27^{* * *}$ & $0.54^{* * *}$ & $0.13^{* * *}$ & $0.18^{* * *}$ \\
& $(0.00)$ & $(0.00)$ & $(0.00)$ & $(0.00)$ \\
REFORM & $-0.03^{* *}$ & 0.01 & $-0.01^{* *}$ & -0.00 \\
& $(0.04)$ & $(0.56)$ & $(0.01)$ & $(0.61)$ \\
REFORM*EXCESS & & $-0.38^{* *}$ & & -0.07 \\
& & $(0.02)$ & & $(0.15)$ \\
\hline SUM TEST & & 0.16 & & $0.11^{* * *}$ \\
EXCESS+REFORM*EXCES & & $(0.14)$ & & $(0.00)$ \\
\hline YEAR & YES & YES & YES & YES \\
INDUSTRY & YES & YES & YES & YES \\
$\mathrm{N}$ & 627 & 627 & 625 & 625 \\
\hline
\end{tabular}


Table 8 The effect of excess control rights and multiple large shareholders on corporate cash holdings/tunneling: 3SLS regression results with accounting for endogeneity issue of cash holding and other corporate policy variables

Panel A report the results using corporate cash holding as dependent variables, panel B reports the results using inter-corporate loan to total assets as dependent variables. 3SLS approach is used to address the endogeneity issue of corporate policy variables. The results of family firms and nonfamily firms are reported in columns 1-2, and 3-4 respectively. Control variables for panel A include: CASHFLOW, BOARDIND, DUALITY, SECONDLARGE, LEVERAGE, DIVTE, OPCF-SD, SIZE, OPCFTA, M2B, SEO and DEBT MATURITY. Controlling variables for panel B include: CASHFLOW, BOARDIND, DUALITY, SECONDLARGE, LEVERAGE, SIZE, OPCFTA, and ROA. The coefficients of control variables are not reported to save space. Definition of variables are detailed in Appendix A. Standardized beta coefficients; p-values in parentheses. *, **, *** represent significant at $10 \%, 5 \%$ and $1 \%$ level significance respectively.

Panel A Corporate cash holding as dependent variable

\begin{tabular}{lcccc}
\hline & \multicolumn{2}{c}{ FAMILY } & \multicolumn{2}{c}{ Non-FAMILY } \\
& CASHTA & CASHTA & CASHTA & CASHTA \\
\hline EXCESS & 0.01 & -0.00 & 0.13 & -0.00 \\
& $(0.78)$ & $(0.92)$ & $(0.45)$ & $(0.99)$ \\
SUM2_10 & $-0.01^{*}$ & & 0.01 & \\
& $(0.07)$ & & $(0.35)$ & \\
EXCESS*SUM2_10 & $0.08^{* *}$ & & -0.13 & \\
SECONDLARGE & $(0.05)$ & & $(0.24)$ & \\
& & -0.01 & & -0.01 \\
EXCESS*SECONDLARGE & & $(0.36)$ & & $(0.48)$ \\
& & $0.16^{*}$ & & -0.04 \\
SUM TEST & & $(0.07)$ & & $(0.67)$ \\
\hline YEAR & $0.14^{* * *}$ & $0.17^{* * *}$ & -0.03 & -0.09 \\
INDUSTRY & $(0.00)$ & $(0.00)$ & $(0.49)$ & $(0.12)$ \\
N & YES & YES & YES & YES \\
\hline
\end{tabular}

Panel B Controlling shareholders' tunneling as dependent variable

\begin{tabular}{lcccc}
\hline & \multicolumn{2}{c}{ FAMILY } & \multicolumn{2}{c}{ Non-FAMILY } \\
& ORECTA & ORECTA & ORECTA & ORECTA \\
\hline EXCESS & 0.06 & 0.07 & $0.14^{* * *}$ & $0.16^{* * *}$ \\
& $(0.30)$ & $(0.32)$ & $(0.00)$ & $(0.00)$ \\
SUM2_10 & -0.01 & & -0.00 & \\
EXCESS*SUM2_10 & $(0.38)$ & & $(0.48)$ & \\
& $0.12^{* *}$ & & -0.03 & \\
SECONDLARGE & $(0.02)$ & & $(0.14)$ & \\
& & -0.01 & & -0.00 \\
EXCESS*SECONDLARGE & & $(0.57)$ & & $(0.86)$ \\
& & $0.16^{*}$ & & $-0.08^{* *}$ \\
\hline SUM TEST & & $(0.08)$ & & $(0.03)$ \\
\hline YEAR & $0.18^{* * *}$ & $0.23^{* * *}$ & $0.11^{* * *}$ & $0.08^{* * *}$ \\
INDUSTRY & $(0.00)$ & $(0.00)$ & $(0.00)$ & $(0.00)$ \\
$\mathrm{N}$ & YES & YES & YES & YES \\
\hline
\end{tabular}


Table 9 The effect of one child policy/family descendant, excess control rights on corporate cash holding/inter-corporate loans of family firms: 3SLS regression results with accounting for endogeneity issue of inter-corporate loans (cash holding) and other corporate policy variables

Columns 1-4 report the results using corporate cash holding as dependent variables, columns 5-8 reports the results using inter-corporate loan to total assets as dependent variables. 3SLS approach is used to address the endogeneity issue of corporate policy variables. ONECHILD is a dummy equals to 1 if the ultimate controlling shareholder of the family firm only has one child and 0 otherwise. DESCENDENT is a dummy equals to 1 if the firm has been passed or is passing to the second generation and 0 otherwise as a measure of whether the firm has a succession problem or not. Control variables (columns 1-4) include: CASHFLOW, BOARDIND, DUALITY, SECONDLARGE, LEVERAGE, DIVTE, OPCF-SD, SIZE, OPCFTA, M2B, SEO and DEBT MATURITY. Control variables (columns 5-8) include: CASHFLOW, BOARDIND, DUALITY, SECONDLARGE, LEVERAGE, SIZE, OPCFTA, and ROA. The coefficients of control variables are not reported to save space. Definition of variables are detailed in Appendix A. Standardized beta coefficients; pvalues in parentheses. $*, * *, * * *$ represent significant at $10 \%, 5 \%$ and $1 \%$ level significance respectively.

\begin{tabular}{lcccccccc}
\hline & \multicolumn{1}{c}{ FAMILY } \\
\hline & CASHTA & CASHTA & CASHTA & CASHTA & ORECTA & ORECTA & ORECTA & ORECTA \\
\hline EXCESS & $0.08^{*}$ & 0.00 & $0.10^{* *}$ & 0.04 & $0.11^{* *}$ & 0.03 & $0.17^{* * *}$ & 0.07 \\
& $(0.06)$ & $(0.95)$ & $(0.01)$ & $(0.44)$ & $(0.03)$ & $(0.66)$ & $(0.00)$ & $(0.33)$ \\
ONECHILD & $0.01^{* *}$ & -0.00 & & -0.00 & $0.01^{*}$ & -0.00 & & -0.00 \\
& $(0.03)$ & $(0.82)$ & & $(0.87)$ & $(0.06)$ & $(0.74)$ & & $(0.83)$ \\
EXCESS*ONECHILD & & $0.16^{* *}$ & & $0.13^{*}$ & & $0.17^{* *}$ & & $0.15^{*}$ \\
& & $(0.02)$ & & $(0.07)$ & & $(0.05)$ & & $(0.09)$ \\
DESCENDANT & $-0.02^{* *}$ & & -0.00 & -0.00 & -0.00 & & 0.01 & 0.01 \\
& $(0.01)$ & & $(0.81)$ & $(0.90)$ & $(0.59)$ & & $(0.31)$ & $(0.37)$ \\
EXCESS*DESCENDANT & & & $-0.19 * *$ & $-0.17^{*}$ & & & $-0.22^{*}$ & -0.18 \\
& & & $(0.04)$ & $(0.08)$ & & & $(0.06)$ & $(0.14)$ \\
\hline SUM TEST & & $0.16^{* * *}$ & -0.09 & 0.00 & & $0.20^{* * *}$ & -0.05 & 0.04 \\
& & $(0.00)$ & $(0.26)$ & $(0.93)$ & & $(0.00)$ & $(0.54)$ & $(0.82)$ \\
\hline YEAR & YES & YES & YES & YES & YES & YES & YES & YES \\
INDUSTRY & YES & YES & YES & YES & YES & YES & YES & YES \\
$\mathrm{N}$ & 1201 & 1201 & 1201 & 1201 & 1201 & 1201 & 1201 & 1201 \\
\hline
\end{tabular}


Table 10 Social trust/political connections, excess control rights and cash holding/tunneling: 3SLS regression results with accounting for endogeneity issue of inter-corporate loans (cash holding) and other corporate policy variables

Columns 1 - 4 report the results using corporate cash holding as dependent variables, columns 5 - 8 reports the results using inter-corporate loan to total assets as dependent variables. 3SLS approach is used to address the endogeneity issue of corporate policy variables. SOCIALTRUST is a dummy equals to 1 if the firm's ultimate controlling shareholder is an executive member of the Chinese Chamber of Commerce and 0 otherwise. POLITICAL is a dummy equals to 1 if the firm's ultimate controlling shareholder is politically connected and 0 otherwise. Control variables (columns 1-4) include: CASHFLOW, BOARDIND, DUALITY, SECONDLARGE, LEVERAGE, DIVTE, OPCFSD, SIZE, OPCFTA, M2B, SEO and DEBT MATURITY. Control variables (columns 5-8) include: CASHFLOW, BOARDIND, DUALITY, SECONDLARGE, LEVERAGE, SIZE, OPCFTA, and ROA. The coefficients of control variables are not reported to save space. Definition of variables are detailed in Appendix A. Standardized beta coefficients; p-values in parentheses. *, **, *** represent significant at $10 \%, 5 \%$ and $1 \%$ level significance respectively.

\begin{tabular}{lcccccccc}
\hline Var. & \multicolumn{1}{c}{ FAMILY } \\
\hline & CASHTA & CASHTA & CASHTA & CASHTA & ORECTA & ORECTA & ORECTA & ORECTA \\
\hline EXCESS & $0.10^{* *}$ & $0.16^{* *}$ & 0.03 & 0.06 & $0.12^{* *}$ & $0.19^{* * *}$ & 0.03 & 0.07 \\
& $(0.01)$ & $(0.04)$ & $(0.49)$ & $(0.25)$ & $(0.02)$ & $(0.00)$ & $(0.66)$ & $(0.26)$ \\
SOCIAL TRUST & $-0.03^{* * *}$ & 0.00 & & $-0.02^{* *}$ & 0.00 & 0.01 & & $0.02^{*}$ \\
& $(0.00)$ & $(0.96)$ & & $(0.02)$ & $(0.93)$ & $(0.57)$ & & $(0.10)$ \\
EXCESS*SOCIAL TRUST & & $-0.19^{* *}$ & & -0.05 & & $-0.13^{*}$ & & $-0.19^{* *}$ \\
& & $(0.03)$ & & $(0.36)$ & & $(0.10)$ & & $(0.01)$ \\
POLITICAL & $0.01^{* *}$ & & 0.01 & 0.00 & $0.02^{* *}$ & & -0.01 & -0.00 \\
& $(0.02)$ & & $(0.46)$ & $(0.86)$ & $(0.01)$ & & $(0.60)$ & $(0.93)$ \\
EXCESS*POLITICAL & & & $0.14^{* *}$ & $0.14^{* *}$ & & & $0.24^{* * *}$ & $0.27^{* * *}$ \\
& & & $(0.04)$ & $(0.04)$ & & & $(0.01)$ & $(0.00)$ \\
\hline SUM TEST & & -0.03 & $0.17^{* * *}$ & $0.15^{* *}$ & & 0.06 & $0.27^{* * *}$ & $0.15^{*}$ \\
& & $(0.66)$ & $(0.00)$ & $(0.03)$ & & $(0.34)$ & $(0.00)$ & $(0.08)$ \\
\hline YEAR & YES & YES & YES & YES & YES & YES & YES & YES \\
INDUSTRY & YES & YES & YES & YES & YES & YES & YES & YES \\
N & 1201 & 1201 & 1201 & 1201 & 1201 & 1201 & 1201 & 1201 \\
\hline
\end{tabular}


Table 11 The effect of family involvement and excess control rights on corporate cash holdings/tunneling of family firms: 3SLS regression results with accounting for endogeneity issue of inter-corporate loans (cash holding) and other corporate policy variables

Columns 1 and 2 report the results using corporate cash holding as dependent variables, columns 3 and 4 reports the results using inter-corporate loan to total assets as dependent variables. 3SLS approach is used to address the endogeneity issue of corporate policy variables. FAMILYCEO is a dummy equals to 1 if members of the controlling family involve in firm management and business operations as a CEO or chairman. Control variables (columns 1-2) include: CASHFLOW, BOARDIND, DUALITY, SECONDLARGE, LEVERAGE, DIVTE, OPCF-SD, SIZE, OPCFTA, M2B, SEO and DEBT MATURITY. Control variables (columns 3-4) include: CASHFLOW, BOARDIND, DUALITY, SECONDLARGE, LEVERAGE, SIZE, OPCFTA, and ROA. The coefficients of control variables are not reported to save space. Definition of variables are detailed in Appendix A. Standardized beta coefficients; p-values in parentheses. *, **, *** represent significant at $10 \%, 5 \%$ and $1 \%$ level significance respectively.

\begin{tabular}{lcccc}
\hline & \multicolumn{4}{c}{ FAMILY } \\
& CASHTA & CASHTA & ORECTA & ORECTA \\
\hline EXCESS & $0.09^{* *}$ & 0.03 & $0.14^{* * *}$ & 0.04 \\
& $(0.05)$ & $(0.47)$ & $(0.01)$ & $(0.57)$ \\
FAMILYCEO & $0.01^{* *}$ & -0.01 & 0.01 & -0.01 \\
& $(0.03)$ & $(0.31)$ & $(0.16)$ & $(0.62)$ \\
EXCESS*FAMILYCEO & & $0.13^{*}$ & & $0.15^{*}$ \\
& & $(0.08)$ & & $(0.09)$ \\
\hline SUM TEST & & $0.17^{* *}$ & & $0.19^{* * *}$ \\
& & $(0.03)$ & & $(0.00)$ \\
\hline YEAR & YES & YES & YES & YES \\
INDUSTRY & YES & YES & YES & YES \\
$\mathrm{N}$ & 1201 & 1201 & 1201 & 1201 \\
\hline
\end{tabular}


Table 12 The GMM dynamic model of the effect of tunneling on corporate cash holdings in family firms

Column 1 and 2 tabulate the results in family firms with low and high excess control rights, respectively. The dependent variable is CASHTA. The independent variable $\mathrm{X}, \mathrm{X}_{\mathrm{t}-1}$ and $\mathrm{X}_{\mathrm{t}-2}$ are the current, one year lagged and two year lagged variable $\mathrm{X}$. The coefficients of control variables are not reported to save space. Definitions of variables are detailed in Appendix A. Standardized beta coefficients; p-value is reported in parentheses. *, **, *** represent significant at $10 \%, 5 \%$ and $1 \%$ level of significance respectively.

\begin{tabular}{lcc}
\hline & \multicolumn{2}{c}{ FAMILY } \\
\cline { 2 - 3 } & Low Excess & High Excess \\
\cline { 2 - 3 } CASHTA $_{\mathrm{t}-1}$ & CASHTA & CASHTA \\
\cline { 2 - 3 } ORECTA & $0.21^{* *}$ & $0.15^{* *}$ \\
& $(0.05)$ & $(0.04)$ \\
ORECTA & -0.19 & $0.03^{*}$ \\
& $(0.61)$ & $(0.07)$ \\
YEAR & 0.15 & $-0.06^{* * *}$ \\
INDUSTRY & $(0.55)$ & $(0.00)$ \\
Wald chi2 & YES & YES \\
\hline
\end{tabular}

Table 13 Dynamic relationship between change of tunneling and change of corporate cash holding in firms with and without excess control rights: 3SLS regression results with accounting for endogeneity issue of inter-corporate loans (cash holding) and other corporate policy variables

The column 1 and 2 tabulate the results in family firms with low and high excess control rights, respectively. The dependent variable $\triangle$ CASHTA is the change of corporate cash holding at year $t$. Among the independent variables: $\triangle$ CASHTA $_{t-1}$ is the change of cash holding at year $\mathrm{t}-1$; $\triangle$ ORECTA $_{\mathrm{t}-1}$ is the change of tunneling at year $\mathrm{t}-1$. Control variables include: $\triangle$ CASHFLOW; $\triangle$ BOARDIND; $\triangle$ DUALITY; $\triangle$ SECONDLARGE; $\triangle$ LEVERAGE; $\triangle$ DIVTE; $\triangle$ DEBT MATURITY; $\triangle$ OPCFTA-SD; $\triangle$ SIZE; $\triangle$ OPCFTA; $\triangle \mathrm{M} 2 \mathrm{~B}$; and $\triangle \mathrm{SEO}$, which are change of all control variables as defined in Appendix A. 3SLS approach is used to address the endogeneity issue of corporate policy variables. The coefficients of control variables are not reported to save space. Standardized beta coefficients; p-value is reported in parentheses. *, **, *** represent significant at $10 \%, 5 \%$ and $1 \%$ level of significance respectively.

\begin{tabular}{lcc}
\hline & Low Excess & High Excess \\
\hline$\Delta$ CASHTA $_{\mathrm{t}-1}$ & $\Delta$ CASHTA & $\Delta$ CASHTA \\
\hline \multirow{2}{*}{ ORECTA $_{\mathrm{t}-1}$} & -0.06 & $-0.10^{* * *}$ \\
& $(0.32)$ & $(0.00)$ \\
\hline YEAR & -0.07 & $-0.04^{* *}$ \\
INDUSTRY & $(0.68)$ & $(0.02)$ \\
$\mathrm{N}$ & YES & YES \\
\hline
\end{tabular}


Table 14 The effect of excess control rights on corporate cash holdings and inter-corporate loans in financial distressed and non-financial distressed firms: 3SLS regression results with accounting for endogeneity issue of inter-corporate loans (cash holding) and other corporate policy variables

Financial distressed firms (DISTRESSED)/non-financial distressed firms (Non-DISTRESSED) are firms whose operation income/interest payment is less (more) than 1. 3SLS approach is used to address the endogeneity issue of corporate policy variables. Control variables (columns 1-2) include: CASHFLOW, BOARDIND, DUALITY, SECONDLARGE, LEVERAGE, DIVTE, OPCF-SD, SIZE, OPCFTA, M2B, SEO and DEBT MATURITY. Control variables (columns 3-6) include: CASHFLOW, BOARDIND, DUALITY, SECONDLARGE, LEVERAGE, SIZE, OPCFTA, and ROA. The coefficients of control variables are not reported to save space. Definition of variables are detailed in Appendix A. Standardized beta coefficients; p-values in parentheses. *, **, *** represent significant at $10 \%, 5 \%$ and $1 \%$ level significance respectively.

\begin{tabular}{lcccccc}
\hline & DISTRESSED & Non-DISTRESSED & \multicolumn{2}{c}{ DISTRESSED } & \multicolumn{2}{c}{ Non-DISTRESSED } \\
& CASHTA & CASHTA & ORECTA & ORECTA & ORECTA & ORECTA \\
\hline EXCESS & -0.20 & $0.08^{* *}$ & 0.12 & 0.11 & $0.18^{* * *}$ & 0.08 \\
& $(0.91)$ & $(0.04)$ & $(0.14)$ & $(0.26)$ & $(0.00)$ & $(0.29)$ \\
HCASHM & & & -0.00 & -0.02 & -0.00 & -0.03 \\
& & & $(0.81)$ & $(0.43)$ & $(0.73)$ & $(0.16)$ \\
HCASHM*EXCESS & & & & 0.09 & & $0.24^{*}$ \\
& & & & $(0.62)$ & & $(0.07)$ \\
\hline SUM TEST & & & & 0.20 & & $0.32^{* * *}$ \\
EXCESS+HCASHM*ECESS & YES & YES & YES & YES & YES & YES \\
\hline YEAR & YES & YES & YES & YES & YES & YES \\
INDUSTRY & 99 & 1102 & 99 & 99 & 1102 & 1102 \\
$\mathrm{~N}$ & & & & &
\end{tabular}


Table 15 The effect of excess control rights on corporate cash holdings in family firms with different need of cash: 3SLS regression results with accounting for endogeneity issue of cash holding and other corporate policy variables

This table presents the results of regressions on the effect of excess control rights on corporate cash holdings in the groups of firms divided according to their 'Growth Opportunities', 'Hedging Needs', and Cash Flow Uncertainty'. Dependent variable is the cash holding to total assets. 3SLS approach is used to address the endogeneity issue of corporate policy variables. The 'Growth Opportunities', 'hedging Needs' and 'Cash Flow Uncertainty' is measured by market to book ratio (M2B), correlation between cash flow and investment opportunities (Q) and year standard deviation of operation cash flow (OPCF-SD), respectively. Control variables include: CASHFLOW, BOARDIND, DUALITY, SECONDLARGE, LEVERAGE, DIVTE, OPCF-SD, SIZE, OPCFTA, M2B, SEO and DEBT MATURITY. The coefficients of control variables are not reported to save space. A firm is assigned in the 'Low' or 'High' group when the variable is below or above the median value. Definition of variables are detailed in Appendix A. Standardized beta coefficients; p-values in parentheses. *, **, *** represent significant at $10 \%, 5 \%$ and $1 \%$ level significance respectively.

\begin{tabular}{lcccccc}
\hline & \multicolumn{2}{c}{ Growth Opportunities } & \multicolumn{2}{c}{ Hedging Needs } & \multicolumn{2}{c}{ Cash Flow Uncertainty } \\
& Low & High & Low & High & Low & High \\
\cline { 2 - 6 } & CASHTA & CASHTA & CASHTA & CASHTA & CASHTA & CASHTA \\
\hline EXCESS & $0.13^{* *}$ & -0.09 & 0.08 & -0.18 & $0.19 * * *$ & 0.03 \\
& $(0.04)$ & $(0.42)$ & $(0.10)$ & $(0.55)$ & $(0.00)$ & $(0.57)$ \\
\hline YEAR & YES & YES & YES & YES & YES & YES \\
INSUDTRY & YES & YES & YES & YES & YES & YES \\
$\mathrm{N}$ & 598 & 600 & 598 & 600 & 598 & 600 \\
\hline
\end{tabular}


Table 16 The effect of corporate cash holdings on firm value in family firms

$X_{t}$ is the level of variable $X$ in year $t$ divided by the level of asset in year $t . \mathrm{dX}_{\mathrm{t}}$ is the change in level of $\mathrm{X}$ from year $t$ to year $t-1$ divided by the total asset in year $\left.t\left(\mathrm{X}_{\mathrm{t}}-\mathrm{X}_{\mathrm{t}-1}\right) / \mathrm{A}_{\mathrm{t}}\right) \cdot \mathrm{dX} \mathrm{X}_{\mathrm{t}+1}$ is the change in level of $\mathrm{X}$ from year $t+1$ to year $t$ divided by the total asset in year $\left.t\left(\mathrm{X}_{\mathrm{t}+1}-\mathrm{X}_{\mathrm{t}}\right) / \mathrm{A}_{\mathrm{t}}\right)$. A is the book value of assets. EARNING is the earnings defined as the earnings before interest and tax. NoncashAsset is the net asset which defined as the total asset minus cash. MV is the market value of assets. DIVIDEND is the cash dividend. EXCASHTA is the ratio of excess cash and cash equivalent to total assets. HIGHEXCESS is a dummy equals to 1 if the excess control rights of the firm is more than median and 0 otherwise. $*, * *, * * *$ represent significant at $10 \%, 5 \%$ and $1 \%$ level significance respectively.

\begin{tabular}{|c|c|c|c|c|}
\hline & \multicolumn{2}{|c|}{ FAMILY } & \multicolumn{2}{|c|}{ FAMILY } \\
\hline & Q & Q & $\mathrm{Q}$ & $\mathrm{Q}$ \\
\hline \multirow[t]{2}{*}{ CASHTA } & -0.27 & -0.84 & & \\
\hline & $(0.65)$ & $(0.42)$ & & \\
\hline \multirow[t]{2}{*}{ CASHTA*HIGHEXCESS } & & -0.16 & & \\
\hline & & $(0.88)$ & & \\
\hline \multirow[t]{2}{*}{ EXCASHTA } & & & $0.47 *$ & $0.94 * * *$ \\
\hline & & & $(0.06)$ & $(0.00)$ \\
\hline \multirow[t]{2}{*}{ EXCASHTA*HIGHEXCESS } & & & & $-1.13^{* *}$ \\
\hline & & & & $(0.02)$ \\
\hline \multirow[t]{2}{*}{ HIGHEXCESS } & $-0.35 * * *$ & $-0.32 *$ & $-0.36 * * *$ & $-0.35 * * *$ \\
\hline & $(0.00)$ & $(0.07)$ & $(0.00)$ & $(0.00)$ \\
\hline \multirow[t]{2}{*}{ EARNING } & $3.78 * * *$ & $3.80 * * *$ & $3.68 * * *$ & $3.58 * * *$ \\
\hline & $(0.00)$ & $(0.00)$ & $(0.00)$ & $(0.00)$ \\
\hline \multirow[t]{2}{*}{ dEARNING $\mathrm{t}_{\mathrm{t}}$} & -0.07 & -0.03 & 0.01 & 0.03 \\
\hline & $(0.90)$ & $(0.95)$ & $(0.99)$ & $(0.95)$ \\
\hline \multirow[t]{2}{*}{$\mathrm{dEARNING}_{\mathrm{t}+1}$} & $1.18^{* * *}$ & $1.22^{* * *}$ & $1.24 * * *$ & $1.22 * * *$ \\
\hline & $(0.00)$ & $(0.00)$ & $(0.00)$ & $(0.00)$ \\
\hline \multirow[t]{2}{*}{ dNoncashAsset $_{\mathrm{t}}$} & $-0.67 * * *$ & $-0.68 * * *$ & $-0.64 * * *$ & $-0.65 * * *$ \\
\hline & $(0.00)$ & $(0.00)$ & $(0.00)$ & $(0.00)$ \\
\hline \multirow[t]{2}{*}{ dNoncashAsset $_{\mathrm{t}+1}$} & $0.14^{* * *}$ & $0.13^{* *}$ & $0.13^{* *}$ & $0.13^{* * *}$ \\
\hline & $(0.01)$ & $(0.01)$ & $(0.01)$ & $(0.01)$ \\
\hline \multirow[t]{2}{*}{$\mathrm{dMV}_{\mathrm{t}+1}$} & -0.01 & -0.01 & -0.01 & -0.01 \\
\hline & $(0.64)$ & $(0.67)$ & $(0.63)$ & (0.69) \\
\hline \multirow[t]{2}{*}{ DIVIDEND } & $9.78 * * *$ & $9.79 * * *$ & $9.16^{* * *}$ & $9.49 * * *$ \\
\hline & $(0.00)$ & $(0.00)$ & $(0.00)$ & $(0.00)$ \\
\hline \multirow[t]{2}{*}{$\mathrm{dDIVIDEND}_{\mathrm{t}}$} & $-3.57^{*}$ & $-3.58 *$ & -3.41 & $-3.68 *$ \\
\hline & $(0.10)$ & $(0.10)$ & $(0.11)$ & $(0.09)$ \\
\hline \multirow[t]{2}{*}{$\mathrm{dDIVIDEND}_{\mathrm{t}+1}$} & -0.25 & -0.31 & -0.44 & -0.39 \\
\hline & $(0.84)$ & $(0.81)$ & $(0.73)$ & $(0.76)$ \\
\hline \multirow[t]{2}{*}{ INTERCEPT } & $1.66^{* * *}$ & $1.73^{* * *}$ & $1.61^{* * *}$ & $1.58^{* * *}$ \\
\hline & $(0.00)$ & $(0.00)$ & $(0.00)$ & $(0.00)$ \\
\hline \multirow[t]{2}{*}{ SUM TEST } & & $-1.00 * * *$ & & -0.19* \\
\hline & & $(0.01)$ & & $(0.10)$ \\
\hline YEAR & YES & YES & YES & YES \\
\hline INDUSTRY & YES & YES & YES & YES \\
\hline $\mathrm{N}$ & 1201 & 1201 & 1201 & 1201 \\
\hline
\end{tabular}


Table 17 Family firms versus non-family firms: matching sample using propensity score method

Panel A The univariate test on the distribution of excess control rights in family firms and other privately owned firms

Excess dummy is the percentage of firms with excess control rights, excess control is the average excess control rights. 'Difference test' columns reports both T-test and z value for Wilcoxon test of difference in mean and median. $*$, ** and $* * *$ represent significant at $10 \%, 5 \%$ and $1 \%$ significant level.

\begin{tabular}{lcccccc}
\hline & \multicolumn{2}{c}{ Family firms } & \multicolumn{2}{c}{ Non-Family firms } & \multicolumn{2}{c}{ Difference Tests } \\
& Mean & Median & Mean & Median & T Value & Z value \\
\hline Excess Dummy & 0.88 & 1.00 & 0.89 & 1.00 & -0.01 & 0.00 \\
Excess Control & 0.10 & 0.09 & 0.10 & 0.09 & 0.00 & 0.00 \\
\hline
\end{tabular}

Panel B Distribution of ownership structure in family and non-family firms

\begin{tabular}{lcc}
\hline Type & No. & Percentage \\
\hline Family & 1201 & $55.02 \%$ \\
Non-Family & 982 & $44.98 \%$ \\
Collective Organization & 693 & $31.75 \%$ \\
Foreign & 96 & $4.40 \%$ \\
Others & 193 & $8.84 \%$ \\
Total & 2183 & $100 \%$ \\
\hline
\end{tabular}

Panel C The effect of excess control rights on corporate cash holdings and inter-corporate loans in different types of non-family firms: 3SLS regression results with accounting for endogeneity issue of cash holding and other corporate policy variables

The Non-family firms are divided into three subsamples which include firms controlled by collective organizations, foreign investors and other non-family investors. The column 1 reports results for firms controlled by collective organizations. Foreign controlled firms and firms controlled by other nonfamily investors are presented in column 2 and 3, respectively. Control variables include: CASHFLOW, BOARDIND, DUALITY, SECONDLARGE, LEVERAGE, DIVTE, OPCF-SD, SIZE, OPCFTA, M2B, SEO and DEBT MATURITY. The coefficients of control variables are not reported to save space. Definition of variables are detailed in Appendix A. Standardized beta coefficients; pvalues in parentheses. $*, * *, * * *$ represent significant at $10 \%, 5 \%$ and $1 \%$ level significance respectively.

\begin{tabular}{lccc}
\hline & & CASHTA & \\
& Collective & Foreign & Other \\
\hline EXCESS & -0.04 & -0.07 & $-1.14^{* *}$ \\
& $(0.63)$ & $(0.57)$ & $(0.04)$ \\
\hline YEAR & YES & YES & YES \\
INDUSTRY & YES & YES & YES \\
$\mathrm{N}$ & 693 & 96 & 193 \\
\hline
\end{tabular}

Panel D The differences of corporate cash holdings between family firms and their propensity score matched nonfamily firms 
We match each family controlled firm to a nonfamily controlled firm by using the nearest neighbor method. In MODEL 1, the variables we use to match are excess control rights, controlling shareholders' control rights and industry and year fixed effects. In MODEL 2, the variables we employ to match are contains excess control rights, controlling shareholders' control rights, firm size, leverage ratio, operation cash flow, operation cash flow volatility and industry and year fixed effects. The variables used to match in MODEL 3 are excess control rights, controlling shareholders' control rights and all control variables in equation 1 . The average treatment effect on the treated is report in this table and p-value is reported in parentheses. *, **, *** represent significant at $10 \%, 5 \%$ and $1 \%$ level significance respectively.

\begin{tabular}{lccc}
\hline & MODEL 1 & MODEL 2 & MODEL3 \\
\hline CASHTA & $0.02^{* *}$ & $0.01^{* *}$ & $0.02^{* * *}$ \\
& $(0.02)$ & $(0.03)$ & $(0.00)$ \\
\hline
\end{tabular}




\author{
Variable name \\ Cash holding (CASHTA) \\ High cash dummy (HCASHM) \\ Inter-corporate loans (ORECTA) \\ Capital expenditure (CAPEXTA) \\ Dividend payout ratio (DIVTE) \\ Tobin's Q (Q) \\ Tunneling RPTs (TUNNELING)
}

Excess control rights (EXCESS)

Cash flow rights (CASHFLOW)

NTS reform (REFORM)

Second largest shareholding (SECONDLARGE)

Shares held by second to tenth shareholders (SUM2_10)

One child policy (ONECHILD)

Family descendant

(DESCENDANT)

Social networks (SOCIAL TRUST)

Political connections (POLITICAL)

Family involvement (FAMILYCEO)

Firm size (SIZE)

Market to book (M2B)

Leverage ratio (LEVERAGE)

Dividend payout (DIVTE)

Operation cash flow (PCFTA)

Operating risk (OPCF-SD)

SEO dummy (SEO)

Board independent (BOARDIND)

Duality of CEO (DUALITY)

\section{Detailed definition}

The ratio of cash and equivalent assets to total assets.

A dummy equals to 1 if the firm's cash holding is above mean and 0 otherwise.

The other receivables scaled by total assets .

Total capital expenditure scaled by total assets.

The ratio of cash dividend to earnings.

Market value/replacement value.

Dummy equals to 1 if the firm has RPT in a particular year and the RPT is tunneling related and 0 if the firm has RPT but it is not tunneling related, following Cheung et al., (2006).

Difference between controlling shareholder's control rights and cash flow rights.

The sum of products of the percentage of ownership along the control chains.

Dummy equals to 1 for firm year observations in the post NTS reform period (3 years period after the reform was completed) and equals to 0 for firm year observations before the NTS reform period(from 2004 to the year the reform was started).

Dummy variable equals to 1 if the firm has a second largest shareholder (the largest shareholder except those affiliated with ultimate owner) with more than $5 \%$ control rights, and 0 otherwise. The number of shareholders who hold more than 5\% control rights from the second to tenth largest shareholders except those affiliated with ultimate owners.

Dummy equals to 1 if the ultimate controlling shareholder of the family firm only has one child and 0 otherwise.

A dummy equals to 1 if the firm has been passed or is passing to the second generation and 0 otherwise.

A dummy equals to 1 if the firm's ultimate controlling shareholder is an executive member of the Chinese Chamber of Commerce and 0 otherwise.

A dummy equals to 1 if the firm's ultimate controlling shareholder is politically connected and 0 otherwise.

Dummy that equals to 1 if members of the controlling family involve in firm management and business operations as a CEO or chairman. The natural logarithm of book value of total assets.

Market value (total book value of assets less book value of equity plus market value of equity) of firm asset to book value of firm assets.

The ratio of total debt to total asset.

Dividend per share to earnings per share.

Total operation cash flow scaled by total assets.

Year standard deviation of operation cash flow scaled by total asset.

Dummy equals to one if firm issues seasoned equity during the year.

Independent board of directors to total board of directors.

Dummy variable which equals to one if the chairman and CEO is same person, 0 otherwise. 